\title{
Varying Contents of Sources Affect Tectonic-Setting Discrimination of Sediments: A Case Study from Permian Sandstones in the Eastern Tianshan, Northwestern China
}

\author{
Xiaoran Zhang, ${ }^{1,2}$ Guochun Zhao, ${ }^{1, \star}$ Paul R. Eizenhöfer, ${ }^{3}$ Min Sun, ${ }^{1}$ Yigui Han, ${ }^{1}$ \\ Wenzhu Hou, ${ }^{1}$ Dongxing Liu, ${ }^{4}$ Bo Wang, ${ }^{4}$ Qian Liu, ${ }^{1}$ and Bing Xu ${ }^{4}$ \\ 1. Department of Earth Sciences, University of Hong Kong, Pokfulam Road, Hong Kong, China; \\ 2. Institute of Earth Sciences, Academia Sinica, Taipei 10529, Taiwan; 3. Department of Geology \\ and Environmental Science, University of Pittsburgh, Pittsburgh, Pennsylvania 15260, USA; \\ 4. Department of Geology, Northwest University, Xi'an 710069, China
}

\begin{abstract}
A B S T R A C T
This article reports new geochemical data from Permian sandstones, most probably deposited during a period of postcollisional extension, from the Yamansu, Shaquanzi, and Xingxingxia areas in the Eastern Tianshan, northwestern China, to determine and characterize their provenance and source nature. The medium- to coarse-grained sandstones are composed mainly of angular to subangular quartz and volcanic fragments, with minor plagioclase and/or microcline, suggesting proximal deposition. Although the samples show relatively large variations in $\mathrm{SiO}_{2}\left(59.7-70.8 \mathrm{wt}^{\mathrm{o}}\right), \mathrm{Al}_{2} \mathrm{O}_{3}$ (9.0-14.9 wt \%), and $\mathrm{Fe}_{2} \mathrm{O}_{3 \mathrm{~T}}+\mathrm{MgO}(2.3-5.2 \mathrm{wt} \%)$ contents, they yield low chemical index of alteration values (41-55) but high index of compositional variability values (1.06-1.78), suggestive of their derivation mainly from compositionally immature sources with weak chemical weathering. Their relatively low Zr concentrations (99-225 ppm) and Gd $\mathrm{d}_{\mathrm{N}} /$ $\mathrm{Yb}_{\mathrm{N}}$ ratios (1.20-1.53) manifest insignificant zircon and monazite enrichments. Most of the samples are characterized by upper continental crust-like rare earth element (REE) patterns with $\delta$ Eu values of 0.63-0.99, reflecting dominant contributions from intermediate to felsic rocks. In particular, the Xingxingxia and Shaquanzi samples have relatively low $\mathrm{SiO}_{2} / \mathrm{Al}_{2} \mathrm{O}_{3}$ (4.51-5.82) and $\mathrm{Th} / \mathrm{U}(2.67-3.77)$ ratios but high $\sum \mathrm{REE}$ (total REE) contents (71.8-141.1 ppm), indicative of a low degree of sedimentary sorting/recycling, whereas the Yamansu samples have higher $\mathrm{SiO}_{2} / \mathrm{Al}_{2} \mathrm{O}_{3}(6.30-6.57)$ and $\mathrm{Th} / \mathrm{U}(3.93-5.16)$ ratios but low $\sum$ REE contents (77.1-86.8 ppm), probably indicative of a higher degree of sedimentary recycling or more involvement of recycled materials. Tectonic-setting discrimination using geochemical data from the samples yielded inconsistent results, with the Xingxingxia and Shaquanzi samples dominantly plotted in or adjacent to the active continental margin or continental island arc field, while the Yamansu samples mostly plotted in or adjacent to the passive margin field. Combining our findings with those of previous detrital zircon studies, we suggest that the inconsistent tectonic discriminations of the Permian sandstones most likely resulted from their receiving different proportions of source rocks that have distinct geochemical compositions. This study provides ample evidence that the geochemical compositions of sedimentary rocks within a continuous sequence or in the same depositional tectonic setting can vary significantly as a result of changes in contents of different source materials and thus that the use of tectonic-setting discrimination diagrams requires great caution.
\end{abstract}

Online enhancements: supplemental table.

\section{Introduction}

Depositional tectonic settings of sediments have been broadly divided into oceanic island arc (OIA), continental island arc (CIA), active continental mar-

Manuscript received July 27, 2016; accepted January 17, 2017; electronically published March 21, 2017.

* Author for correspondence; e-mail: gzhao@hkucc.hku.hk.

gin (ACM), and passive margin (PM) in a simplified classification of continental margins and oceanic basins on the basis of the nature (e.g., ancient or young, thick or thin) of crusts (Bhatia 1983; Bhatia and Crook 1986; Roser and Korsch 1986; Floyd et al. 1989; McLennan and Taylor 1991; McLennan et al. 1993). Systematic variations have been documented in geochemical compositions, particularly the "im-

[The Journal of Geology, 2017, volume 125, p. 299-316] (c) 2017 by The University of Chicago. All rights reserved. 0022-1376/2017/12503-0002\$15.00. DOI: 10.1086/691217 
mobile" elements (e.g., La, $\mathrm{Nd}, \mathrm{Sc}, \mathrm{Nb}, \mathrm{Zr}$, and Th), of sediments from different tectonic settings. For example, from OIA to PM settings the bulk-rock $\mathrm{Al}_{2} \mathrm{O}_{3}$, $\mathrm{Fe}_{2} \mathrm{O}_{3 \mathrm{~T}}+\mathrm{MgO}, \mathrm{TiO}_{2}$, and $\mathrm{Al}_{2} \mathrm{O}_{3} / \mathrm{SiO}_{2}$ values of sandstones tend to decrease, whereas $\mathrm{SiO}_{2}$ and $\mathrm{K} 2 \mathrm{O} / \mathrm{Na}_{2} \mathrm{O}$ values generally increase (Bhatia 1983). Likewise, there are general increases in the contents of light rare earth elements (LREEs; e.g., $\mathrm{La}, \mathrm{Ce}$, and $\mathrm{Nd}$ ), large-ion lithophile elements (e.g., $\mathrm{K}, \mathrm{Rb}, \mathrm{Ba}$, and $\mathrm{Sr}$ ), and high-field-strength elements (e.g., $\mathrm{Sc}, \mathrm{Nb}$, $\mathrm{Zr}$, Th, and $\mathrm{U}$ ) and in the ratios $\mathrm{Th} / \mathrm{U}, \mathrm{La} / \mathrm{Sc}, \mathrm{Th} / \mathrm{Sc}$, and $\mathrm{Rb} / \mathrm{Sr}$, together with decreases in the values of $\mathrm{Co}, \mathrm{Sc}, \delta \mathrm{Eu}, \mathrm{Co} / \mathrm{Th}, \mathrm{Zr} / \mathrm{Th}$, and $\mathrm{Ti} / \mathrm{Zr}$, in graywackes from OIA to PM settings (Bhatia 1983; Taylor and McLennan 1985; Bhatia and Crook 1986; Roser and Korsch 1986; McLennan et al. 1993; Eizenhöfer et al. 2015). These variations form the basis for distinguishing the tectonic settings of sediments with geochemical data, with over a dozen discrimination diagrams proposed (Bhatia 1983; Bhatia and Crook 1986; Roser and Korsch 1986; McLennan et al. 1993).

However, their universal validity has been repeatedly questioned (Haughton 1988; Winchester and Max 1989; Shao et al. 2001; Armstrong-Altrin and Verma 2005), as many factors, such as source compositions, source weathering, sedimentary sorting/recycling, and postdepositional alternations, can significantly affect the geochemical compositions of sediments (Bhatia 1983; Bhatia and Crook 1986; Wronkiewicz and Condie 1987; McLennan et al. 1993; Nesbitt and Markovics 1997). In particular, using geochemical data from modern sediments collected from certain depositional tectonic settings, Armstrong-Altrin and Verma (2005) have found that the tectonic-setting discrimination diagrams that are based on major-element compositions yielded very low success rates (mostly $<32 \%$ ) in identifying the correct tectonic settings, although the $\mathrm{K} 2 \mathrm{O} / \mathrm{Na}_{2} \mathrm{O}$ versus- $\mathrm{SiO}_{2}$ discrimination diagram (Roser and Korsch $1986)$ appeared to have higher success rates $(32 \%-$ $62 \%)$. Moreover, the OIA-CIA-ACM-PM tectonicsetting classification by Bhatia (1983) relies heavily on the nature of source materials, which indirectly reflects the depositional tectonic setting of sediments, with some unique or complex settings (e.g., postcollisional extension) hard to categorize. Furthermore, the distinction between the CIA and ACM settings is not well defined (van de Kamp and Leake 1985; Roser and Korsch 1986), and it is not necessary for a specific tectonic setting to deposit sediments with unique geochemical characteristics (e.g., McLennan et al. 1990). Most importantly, previous studies did not pay much attention to variations in geochemical compositions of sediments within a continuous sequence/formation, which may have received variable proportions of different source materials.

Here, we provide a case study from the Eastern Tianshan, northwestern China, to probe geochemical variations in sediments from a continuous sequence and/or from the same depositional setting. The Eastern Tianshan is traditionally divided into the North Tianshan (NTS) accretionary belt, the Central Tianshan (CTS) microcontinent/block, and the South Tianshan (STS) accretionary belt (fig. 1). Diverse components, including Precambrian basement and Paleozoic subduction/collision-related plutonic, volcanic, and sedimentary rocks, as well as Mesozoic granitoid intrusions, occur throughout the CTS block (Hu et al. 1998, 2000, 2006; Xiao et al. 2004; Zhang et al. 2005, 2015a, 2016a, 2016b; Dong et al. 2011; Lei et al. 2013; Ma et al. 2014, 2015; Shi et al. 2014; Liu et al. 2015). Previous investigations indicate that the eastern segment of the South Tianshan Ocean to the south of the CTS block was likely closed in the Devonian (Chen et al. 1999; Charvet et al. 2007, 2011; He et al. 2014; Zhang et al. 2015b, 2016a) and that the Junggar Ocean to the north of the CTS block was closed most probably during latest Carboniferous to earliest Permian time (ca. $300 \mathrm{Ma}$ ), followed by Permian postcollisional extension in the Eastern Tianshan (Xiao et al. 2004; Wang et al. 2007; Shu et al. 2011; Zhang et al. 2016c). It deserves mention that another group of geoscientists favor the view that the final assembly of the Chinese Tianshan occurred in the Permian or Permian to Middle Triassic (e.g., Xiao et al. 2013, 2015). However, their arguments are mostly from the Western Tianshan, rather than the Eastern Tianshan. Moreover, their model is in conflict with recent geological, geochemical, and geochronological investigations (given in detail in the next section) that have reached a consensus that the Eastern Tianshan experienced a postcollisional extension since the Early Permian, with findings such as ca. $295 \mathrm{Ma}$ postcollisional bimodal volcanic rocks (Chen et al. 2011), ca. $290 \mathrm{Ma}$ within-plate basalt-type mafic intrusions (Zhang et al. 2016b), and ca. 290-270 Ma postcollisional ultramafic to felsic rocks (Chen and Shu 2010; Yuan et al. 2010; Su et al. 2012; Wang et al. 2014). Therefore, the Permian sedimentary rocks in the study region were most probably deposited during a period of postcollisional extension.

In this study, Permian sandstones were collected from the NTS and STS belts in the Eastern Tianshan (fig. 2) for geochemical analysis. Specifically, in the NTS belt five samples were collected within a continuous sedimentary sequence $(<20 \mathrm{~m}$ thick $)$ in the Shaquanzi area (fig. $2 b$ ), with three contemporary samples collected $66 \mathrm{~km}$ west in the Yamansu area (fig. 2a). For comparison, two samples were 


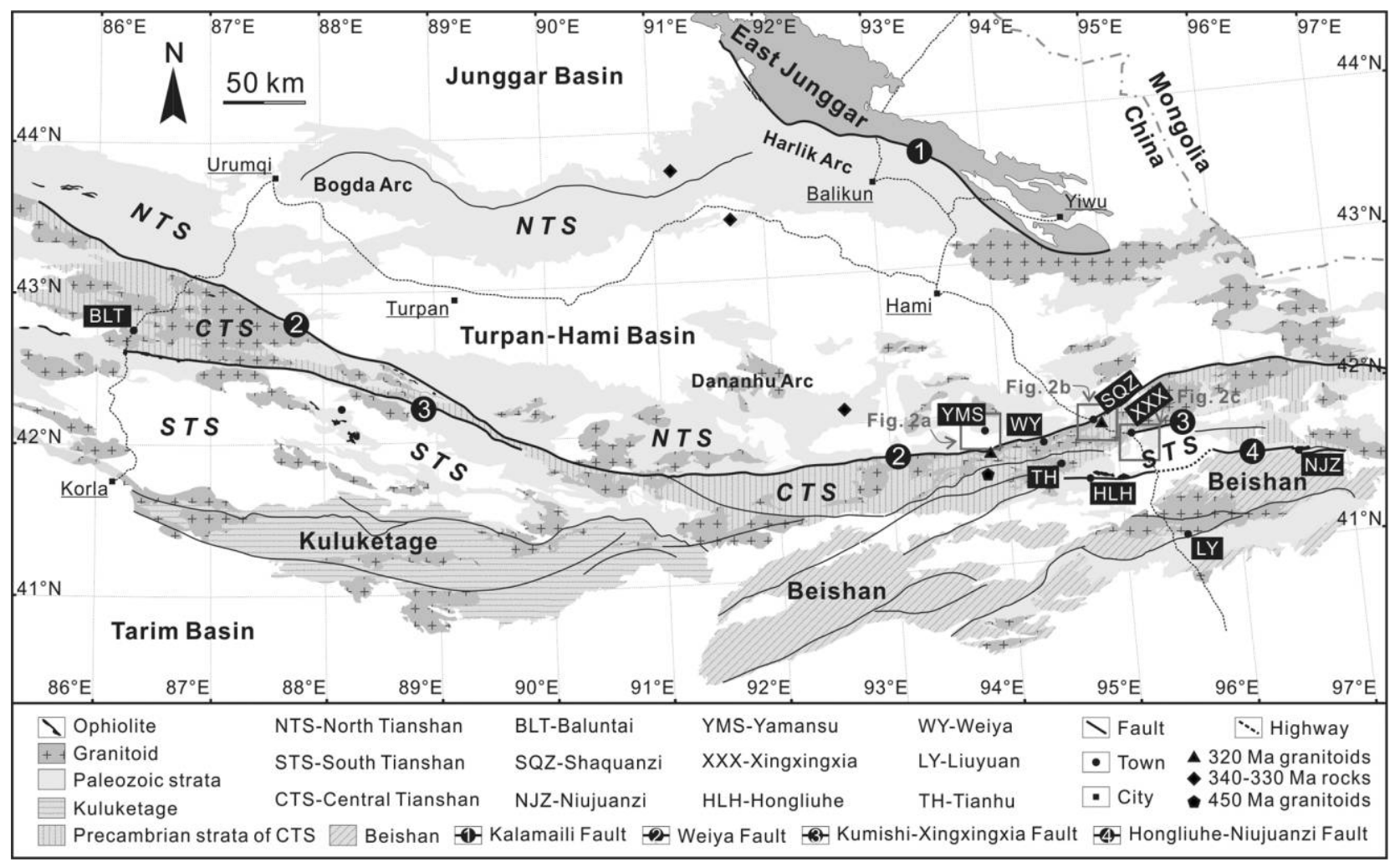

Figure 1. Simplified geological map of the Eastern Tianshan, modified after Zhang et al. (2015b). The 450-320 Ma magmatic rocks are from Hou et al. (2005) and Zhang et al. (2015a, 2016a, 2017). A color version of this figure is available online.

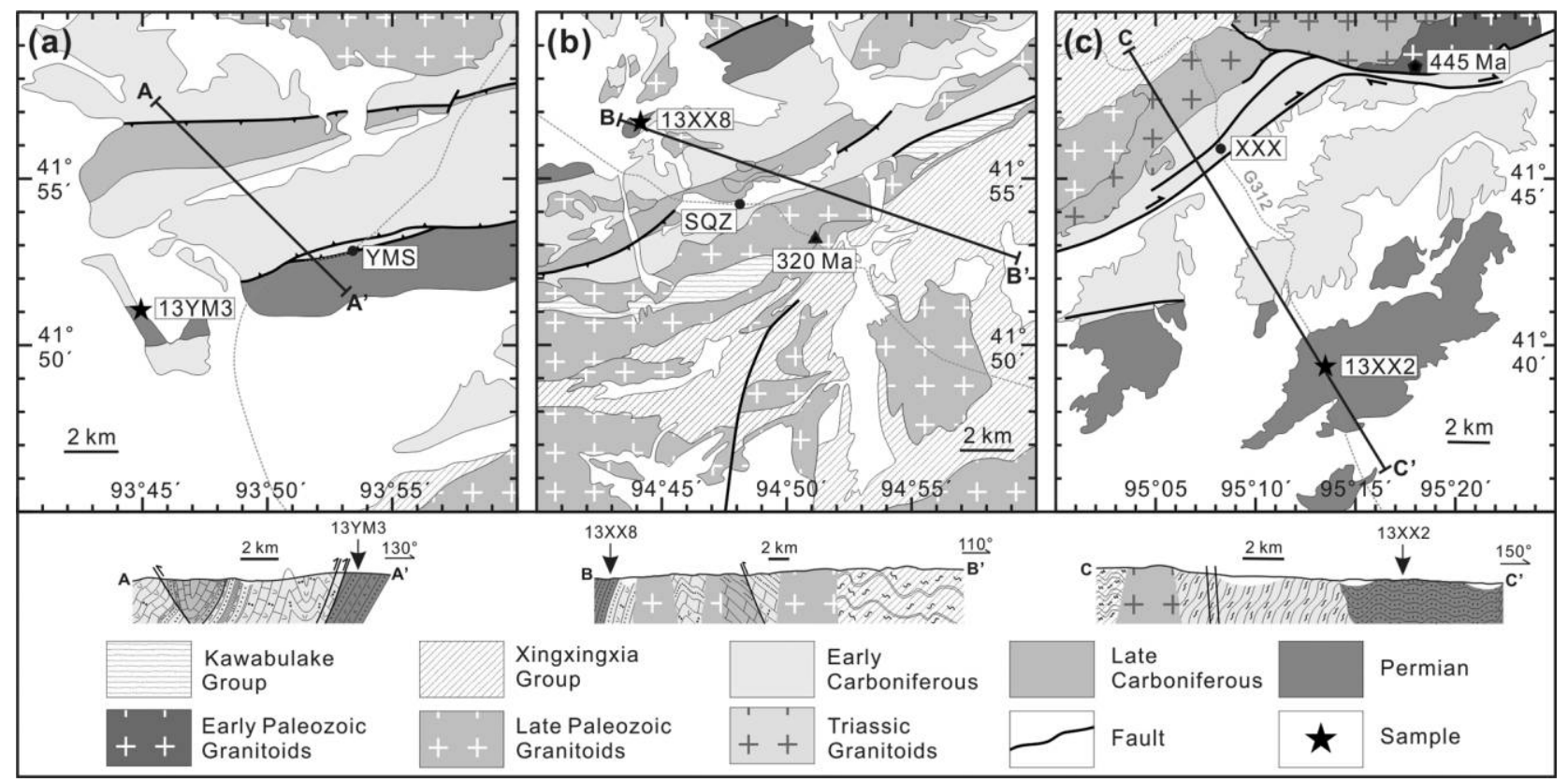

Figure 2. Simplified geological maps of the Yamansu (YMS, a), Shaquanzi (SQZ, b), and Xingxingxia (XXX, c) areas, modified after Zhang et al. $(2016 a, 2016 c)$. Dating results of representative granitoids are from Mao et al. (2010) and Zhang et al. $(2015 a)$. A color version of this figure is available online. 
collected from Permian strata in the Xingxingxia area in the STS belt (fig. 2c). The widely used tectonicsetting discrimination diagrams were applied, yielding inconsistent tectonic settings (CIA, ACM, and PM) for Permian sandstones that should have been deposited in the same depositional tectonic setting (most probably postcollisional extension). Combining these findings with those of previous studies, we argue that such different discrimination results are probably related to the very different contents of their distinct sources (e.g., Precambrian magmatic/sedimentary rocks, Paleozoic subduction-related magmatism, or island arc rocks). Therefore, even for sediments from a continuous sedimentary sequence, the application of tectonic-setting discrimination diagrams requires great caution.

\section{Geological Background}

The Chinese Tianshan, northwestern China, is bordered by the Tarim block to the south and the Junggar terranes (Junggar Basin and East and West Junggar) to the north (Windley et al. 1990; Allen et al. 1993; Gao et al. 1998; Charvet et al. 2007, 2011; Xiao et al. 2012). Roughly along the $86^{\circ} \mathrm{E}$ longitude, it is traditionally subdivided into two segments, namely, the Western and the Eastern Tianshan (Gao et al. 1998; Xiao et al. 2004; Han et al. 2015, 2016a, 2016b, 2016c). The Permian sandstones in this study were collected from the Eastern Tianshan, which is separated from the East Junggar and Beishan terranes by the Kalamaili and the Hongliuhe-Niujuanzi faults, respectively (fig. 1). The Eastern Tianshan is further divided into three tectonic units, including the NTS belt, the CTS block, and the STS belt, by major strike-slip faults (Xiao et al. 2004; Charvet et al. 2007, 2011). Two major oceans, the South Tianshan Ocean between the Tarim and CTS blocks and the Junggar Ocean to the north of the CTS block, have been recognized in the Eastern Tianshan ( $\mathrm{Ma}$ et al. 1997; Zhang et al. 2016a, 2016c).

The NTS accretionary belt was formed during the Paleozoic development of the Junggar Ocean (Ma et al. 1997; Han et al. 2010), as testified to by Cambrian to Carboniferous ophiolitic mélanges (Xu et al. 2006; $\mathrm{Li}$ et al. 2008) as well as Devonian-Carboniferous island arcs (e.g., Bogda, Dananhu, and Yamansu) in the NTS belt. Recent kinematic investigations in the region suggest a primarily southward-directed subduction for the Junggar oceanic plate beneath the Chinese Tianshan (Charvet et al. 2007, 2011; Wang et al. 2014), further substantiated by Ordovician to Late Carboniferous subduction-related magmatism in the CTS block (e.g., Ma et al. 2014; Shi et al. 2014; Zhang et al. 2015a, 2016a). Several lines of evidence lead to a final closure of the Junggar Ocean most probably in the latest Carboniferous to earliest Permian, including (1) ca. $325 \mathrm{Ma}$ ophiolitic rocks in the NTS belt (Xu et al. 2006), (2) ca. 325-320 Ma calc-alkaline granitoids showing subduction-related geochemical signatures on the northern margin of the CTS block (Zhang et al. 2015a), (3) ca. 295 Ma bimodal volcanic rocks with postcollisional geochemical characteristics in the Bogda arc (Chen et al. 2011), (4) ca. $290 \mathrm{Ma}$ mafic intrusions displaying strong within-plate basalt affinities in the CTS block (Zhang et al. 2016b), and (5) Permian postcollisional ultramafic-felsic rocks in the Eastern Tianshan (Chen and Shu 2010; Yuan et al. 2010; Shu et al. 2011; Su et al. 2012; Wang et al. 2014; Ma et al. 2015). Importantly, such a closure time for the Junggar Ocean is further supported by recent paleomagnetic data that suggest the lack of significant relative motion among the tectonic units (e.g., Junggar, Yili, and Tarim blocks) in the region since the Late Carboniferous (Wang et al. 2007) and structural analyses that reveal Carboniferous oceanic subduction/accretion and Early Permian postcollisional transcurrent shearing in the NTS belt (Wang et al. 2014).

The CTS block is composed of diverse components, such as Precambrian magmatic and sedimentary rocks and Paleozoic subduction/collision-related or postcollisional magmatism and sedimentary rocks, as well as Mesozoic intrusions (e.g., Hu et al. 2000; Xiao et al. 2004). The Precambrian basement rocks, divided into the Tianhu, Kawabulag, and Xingxingxia Groups, have been proposed to be Paleoproterozoic to Neoproterozoic in age, consisting mainly of marble, banded gneiss, sericite quartz schist, quartzite, migmatite, and amphibolite. Most of these rocks have experienced greenschist- to amphibolitefacies metamorphism and are unconformably covered by or in fault contact with Paleozoic-Mesozoic strata (Hu et al. 1998, 2006; Lei et al. 2013; He et al. 2014; Liu et al. 2015). Formation of Paleozoic magmatic rocks in the CTS block is attributed to the southward subduction of the Junggar oceanic plate (Ma et al. 1997; Han et al. 2010; Zhang et al. 2015a, $2016 c$ ), to the northward subduction of the South Tianshan oceanic plate (Windley et al. 1990; Allen et al. 1993; Gao et al. 1998), or to (post)collisional tectonothermal events (Zhang et al. 2005; Wu et al. 2010; Dong et al. 2011; Ma et al. 2014, 2015; Shi et al. 2014).

The STS accretionary belt was formed as a result of the Paleozoic evolution (opening, expansion, and closure) of the South Tianshan Ocean, which was initially opened as a backarc basin between the Ta- 
rim and CTS blocks (Gao et al. 1998; Chen et al. 1999; Dong et al. 2011; Han et al. 2011, 2015, 2016a; Wang et al. 2011). Chen et al. (1999) have proposed an eastwest scissors-like closure for the South Tianshan Ocean, with its eastern segment probably closed in the Late Devonian (Charvet et al. 2007, 2011). This consideration is further in accordance with the presence of ca. $380 \mathrm{Ma}$ regional metamorphism in the CTS block and the absence of $<380$ Ma subductionrelated magmatism in the northern Tarim block and the southern part of the CTS block (He et al. 2014; Zhang et al. 2015b, 2016a).

Accordingly, the final assembly of the Eastern Tianshan most probably took place during the Late Carboniferous to Early Permian, followed by extensive postcollisional extension in the Permian. The Permian sedimentary rocks in the region were most probably deposited in a postcollisional extension setting.

\section{Sampling and Analytical Methods}

A total of 10 fresh, unmetamorphosed, and undeformed sandstone samples from the Eastern Tianshan were analyzed in this study, with detailed sample locations in figure 2 and representative photomicrographs shown in figure 3 . In particular, eight samples were collected from the Permian strata in the NTS belt, including five samples, 13XX8A13XX8E, from the Shaquanzi area and three samples, 13YM3A-13YM3C, from the Yamansu area (fig. 2a, $2 b)$. The Shaquanzi samples were collected from a continuous sequence less than $20 \mathrm{~m}$ in thickness, with samples 13XX8E and 13XX8D from the lower layers and samples $13 \mathrm{XX} 8 \mathrm{C}-13 \mathrm{XX} 8 \mathrm{~A}$ from the upper layers. Most of the samples are medium to coarse grained and are composed dominantly of angular to subangular quartz, feldspar, and volcanic fragments, suggesting proximal deposition (fig. 3). Our recent detrital zircon studies indicate that the maximum depositional ages (MDAs) are ca. 294, 292, 258, and $281 \mathrm{Ma}$ for samples 13XX8E, 13XX8D, 13XX8C, and 13YM3C, respectively, with Precambrian-Early Paleozoic detrital grains in these samples dominantly derived from the CTS block and DevonianPermian detrital zircons mainly sourced from coeval island arc rocks in the NTS belt (Zhang et al. 2016c).

In addition, two sandstone samples, 13XX2A and 13XX2B, were selected from the Permian strata in the STS belt for comparison (fig. 2c). Subangular quartz and lithic fragments are the main framework constituents, indicating proximal deposition (fig. 3). Our recent detrital zircon study reveals an
MDA of ca. $256 \mathrm{Ma}$ for sample 13XX2A, with detrital zircons mostly derived from the southern margin of the CTS block (Zhang et al. 2015b).

Whole-rock major-element concentrations of the Permian sandstones were analyzed by an Axios ${ }^{\max }$ X-ray fluorescence spectrometer at the Hebei Geology and Resource Bureau (Langfang, China). Analytical precisions are generally better than $2 \%$. Trace-element compositions of the sandstones were measured at the Guiyang Institute of Geochemistry (Guiyang, China), using an inductively coupled plasma mass spectrometry (ICP-MS) system, with analytical uncertainties mostly less than $10 \%$. Detailed analytical procedures are similar to those described by Qi et al. (2000). Major- and trace-element compositions of the Permian sandstones from the Eastern Tianshan are shown in table S1, available online.

\section{Results}

Major Elements. The Yamansu samples (13YM3A$13 \mathrm{YM} 3 \mathrm{C}$ ) show restricted variations in major-element compositions, containing $\mathrm{SiO}_{2}$ at $69.3-70.8 \mathrm{wt} \%$, $\mathrm{Al}_{2} \mathrm{O}_{3}$ at $10.7-11.0 \mathrm{wt} \%, \mathrm{Fe}_{2} \mathrm{O}_{3 \mathrm{~T}}$ at $1.6-2.0 \mathrm{wt} \%$, $\mathrm{CaO}$ at $4.7-5.4 \mathrm{wt} \%, \mathrm{~K}_{2} \mathrm{O}$ at $2.9-3.0 \mathrm{wt} \%$, and $\mathrm{Na}_{2} \mathrm{O}$ at $2.1-2.4 \mathrm{wt} \%$. They generally plot in the litharenite field in the $\mathrm{SiO}_{2} / \mathrm{Al}_{2} \mathrm{O}_{3}$-versus- $\mathrm{Na}_{2} \mathrm{O} / \mathrm{K}_{2} \mathrm{O}$ classification diagram (fig. 4; after Pettijohn et al. 1972). The Shaquanzi samples (13XX8A-13XX8E) have relatively high loss-on-ignition values $(6.3-11.0 \mathrm{wt} \%)$, probably resulting from their very high calcite contents in the matrix (fig. 3a-3d). They have relatively lower contents of $\mathrm{SiO}_{2}(59.7-66.6 \mathrm{wt} \%)$ and $\mathrm{K}_{2} \mathrm{O}$ (1.2-2.6 wt \%) but generally higher contents of $\mathrm{Al}_{2} \mathrm{O}_{3}$ $(9.0-11.9 \mathrm{wt} \%), \mathrm{Fe}_{2} \mathrm{O}_{3 \mathrm{~T}}(2.2-3.6 \mathrm{wt} \%), \mathrm{CaO}$ (6.9$12.6 \mathrm{wt} \%)$, and $\mathrm{Na}_{2} \mathrm{O}(2.5-4.6 \mathrm{wt} \%)$, dominantly plotted in the graywacke field (fig. 4). The Xingxingxia samples (13XX2A and 13XX2B) exhibit consistent $\mathrm{SiO}_{2}$ at 67.1-67.2 wt\%, $\mathrm{Al}_{2} \mathrm{O}_{3}$ at $14.4-14.9 \mathrm{wt} \%$, $\mathrm{Fe}_{2} \mathrm{O}_{3 \mathrm{~T}}$ at $2.5-3.2 \mathrm{wt} \%, \mathrm{CaO}$ at $3.7 \mathrm{wt} \%, \mathrm{~K}_{2} \mathrm{O}$ at $2.2-$ $2.4 \mathrm{wt} \%$, and $\mathrm{Na}_{2} \mathrm{O}$ at $2.9-3.3 \mathrm{wt} \%$, plotted in the graywacke field (fig. 4).

Trace Elements. All the analyzed Permian sandstones show LREE-enriched REE patterns (fig. $5 a-$ $5 c$; chondrite data from McDonough and Sun 1995), with $\mathrm{La}_{\mathrm{N}} / \mathrm{Yb}_{\mathrm{N}}$ and $\mathrm{Gd}_{\mathrm{N}} / \mathrm{Yb}_{\mathrm{N}}$ ratios of $9.32-12.28$ and 1.20-1.53, respectively. In particular, the Yamansu samples are characterized by low $\sum$ REE (total REE) contents of 77.1-86.8 ppm and obvious negative $\mathrm{Eu}$ anomalies $(\delta \mathrm{Eu}=0.70-0.75$; fig. $5 a)$, showing REE patterns similar to, but lower than, that of upper continental crust (UCC; data from Rudnick and Gao 2003). The Shaquanzi samples have variable $\sum$ REE 



Figure 3. Representative photomicrographs of the Permian sandstones from the Eastern Tianshan. Cal $=$ calcite; $\mathrm{Pl}=$ plagioclase $; \mathrm{Q}=$ quartz; Ser $=$ sericite. A color version of this figure is available online.

contents of 71.8-111.6 ppm and obvious to negligible $\mathrm{Eu}$ anomalies $(\delta \mathrm{Eu}=0.70-0.99$; fig. $5 b)$. The Xingxingxia samples have relatively higher $\sum$ REE contents (113.6-141.1 ppm) and obvious negative Eu anomalies $(\delta \mathrm{Eu}=0.70-0.74)$, with UCC-like REE patterns (fig. $5 c$ ). In the trace-element spidergrams (continental-crust and primitive-mantle data from Rudnick and Gao 2003 and McDonough and Sun 1995, respectively), the Xingxingxia samples display distributions of trace elements nearly identical to that 


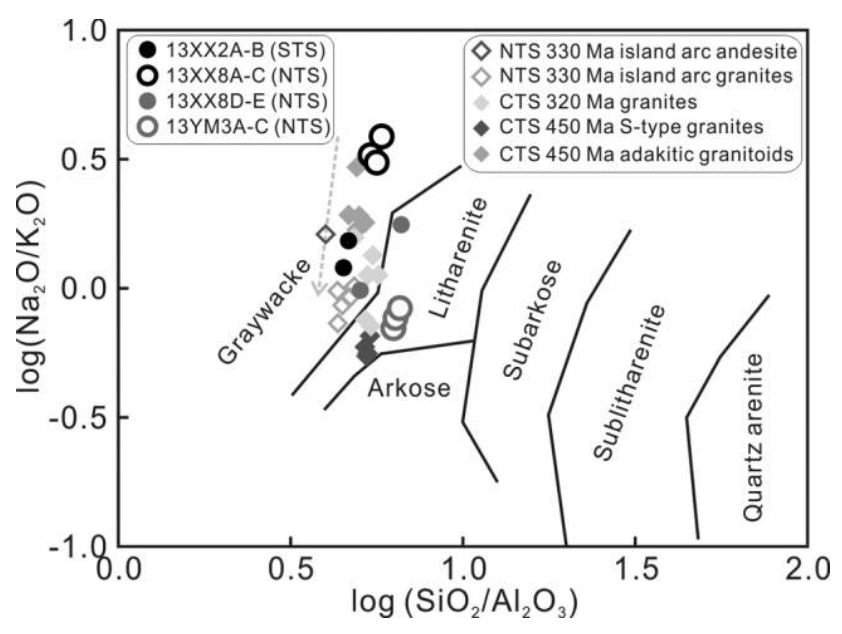

Figure 4. $\mathrm{SiO}_{2} / \mathrm{Al}_{2} \mathrm{O}_{3}$-versus $-\mathrm{Na}_{2} \mathrm{O} / \mathrm{K}_{2} \mathrm{O}$ classification diagram (Pettijohn et al. 1972) for the Permian sandstones from the Eastern Tianshan. Data for 450-320 Ma magmatic rocks are from Hou et al. (2005) and Zhang et al. $(2015 a, 2016 a, 2017)$. CTS $=$ Central Tianshan; NTS $=$ North Tianshan; STS = South Tianshan. A color version of this figure is available online.

of UCC, with the Yamansu samples showing UCClike but lower patterns and the Shaquanzi samples exhibiting mixed patterns that are situated between those of lower continental crust (LCC) and UCC.
In addition, systematic variations in the concentrations or ratios of trace elements can be observed in the Shaquanzi samples. For example, from the oldest (lowest) sample 13XX8E to the younger (upper) samples 13XX8C-13XX8A, there are general increases in $\mathrm{Zr}$ (from 110 to $135 \mathrm{ppm}$ ), Sr (from 321 to $421 \mathrm{ppm}$ ), Sr/Y (from 19.1 to 31.4), Sc/Th (from 0.9 to 1.4 ), $\mathrm{Zr} / \mathrm{Th}$ (from 15.3 to 21.3 ), and $\delta \mathrm{Eu}$ (from 0.7 to 1.0) values and decreases in $\mathrm{K}_{2} \mathrm{O} / \mathrm{Na}_{2} \mathrm{O}$ (from 0.57 to 0.26 ), $\mathrm{Cr}$ (from 92 to $37 \mathrm{ppm}$ ), Ni (from 45 to $14 \mathrm{ppm}$ ), $\sum$ REE (from 97 to $72 \mathrm{ppm}$ ), La/Sc (from 3.38 to 2.06 ), $\mathrm{Rb} / \mathrm{Sr}$ (from 0.21 to 0.12 ), and $\mathrm{Cr} / \mathrm{Th}$ (from 12.8 to 5.4 ) values (table S1).

\section{Discussion}

Geochemical compositions of sedimentary rocks are predominantly controlled by the geochemistry of their sources and can be influenced by (1) chemical weathering (Nesbitt and Young 1982), (2) sedimentary sorting/recycling during transport and sedimentation (McLennan et al. 1993; Cullers 1994, 1995), and (3) postdepositional alternations (e.g., silicification, K-metasomatism, and metamorphism; Fedo et al. 1995, 1996). In turn, the geochemistry of sediments can be used to constrain these processes (Nesbitt and Young 1982; Taylor and McLennan 1985;
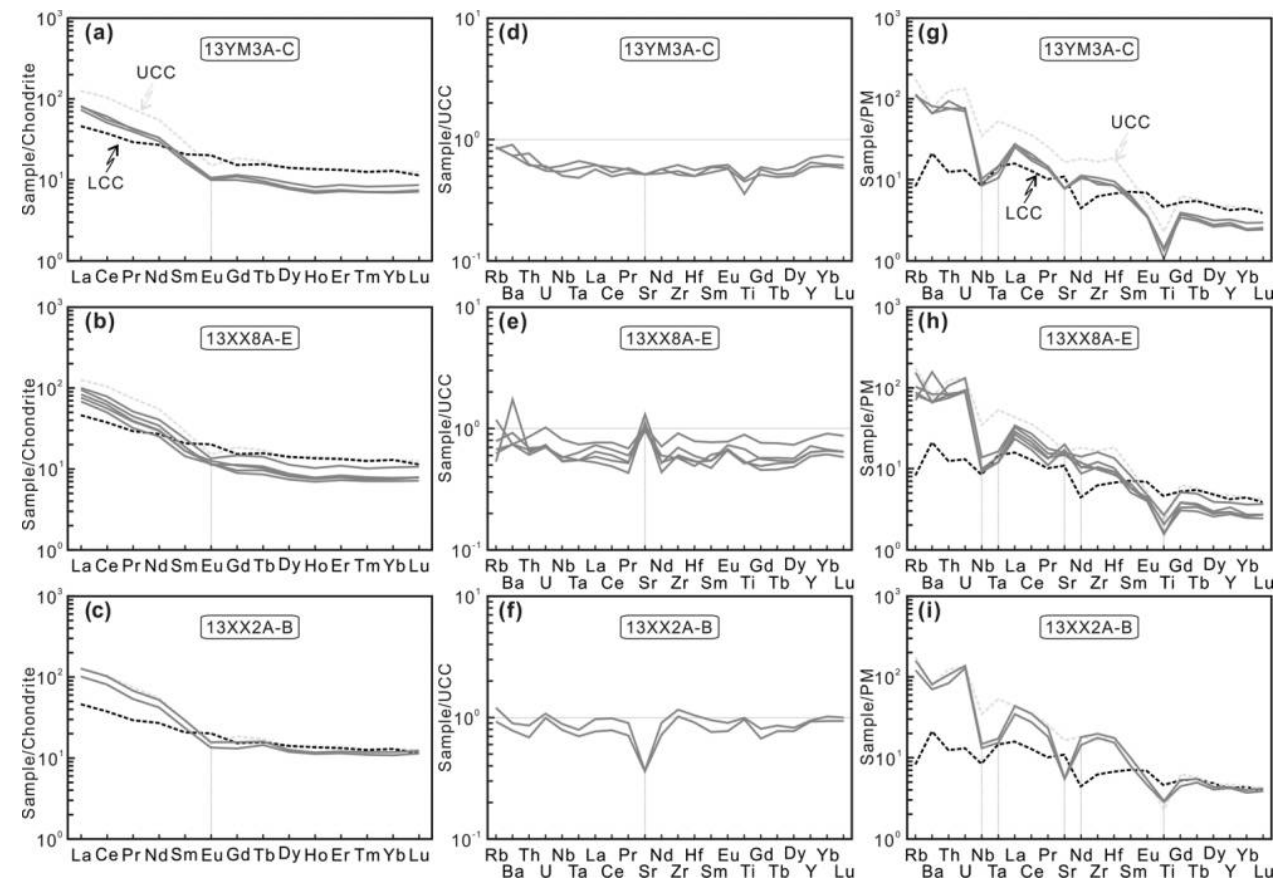

Figure 5. Chondrite-normalized rare earth element patterns and upper continental crust (UCC)- and primitive mantle (PM)-normalized trace-element spidergrams for the Permian sandstones from the Eastern Tianshan. Chondrite and PM compositions are from McDonough and Sun (1995), with UCC compositions from Rudnick and Gao (2003). LCC $=$ lower continental crust. A color version of this figure is available online. 
McLennan et al. 1993; Fedo et al. 1995). In particular, certain trace elements (e.g., Th and Sc) and REEs are generally considered reliable indicators of sedimentary provenance because of their relatively negligible mobility during sedimentary processes and low potential to be influenced by heavy-mineral fractionation (Bhatia 1983; Taylor and McLennan 1985; Bhatia and Crook 1986). These elements, as well as the ratios between them, may preserve the initial geochemical signatures of source materials and thus may provide insight into source nature and sedimentary provenance (Bhatia 1983; Bhatia and Crook 1986; Floyd et al. 1989; Cullers et al. 1993; Cullers 1994, 1995).

Weathering and Postdepositional Alterations. Weathering commonly involves the conversion of lithic fragments, as well as unstable minerals (e.g., biotite, muscovite), to clay minerals. The chemical index of alteration (also CIA; molecular $\mathrm{Al}_{2} \mathrm{O}_{3} /\left(\mathrm{Al}_{2} \mathrm{O}_{3}+\right.$ $\left.\mathrm{CaO}^{*}+\mathrm{Na}_{2} \mathrm{O}+\mathrm{K}_{2} \mathrm{O}\right) \times 100$ ), in which $\mathrm{CaO}^{*}$ represents the $\mathrm{CaO}$ incorporated in silicate minerals, is commonly used to quantify the intensity of source weathering (Nesbitt and Young 1982, 1984; McLennan et al. 1993; Fedo et al. 1995). For example, fresh UCC has an average CIA value of 48, moderately weathered post-Archean average shales (PAASs) show CIA values of 70-75, and clay minerals (e.g., kaolinite and gibbsite) yield CIA values near 100 (McLennan et al. 1993; Rudnick and Gao 2003). The Permian sandstones in this study have very low CIA values of 41-55 (fig. 6), indicative of very weak weathering or a general lack of clay minerals in the source areas. In particular, the Xingxingxia samples (13XX2A and 13XX2B) have higher CIA values (52-55) than the Shaquanzi (13XX8A-13XX8E) and Yamansu (13YM3A13YM3C) samples (41-52), consistent with their having higher $\mathrm{Al}_{2} \mathrm{O}_{3}$ contents (14.4-14.9 wt\%) than the latter $(9.0-11.8 \mathrm{wt} \%)$.

In addition, as clay minerals contain higher $\mathrm{Al}_{2} \mathrm{O}_{3}$ but lower $\mathrm{K}_{2} \mathrm{O}, \mathrm{Na}_{2} \mathrm{O}$, and $\mathrm{CaO}$ contents than do nonclay minerals (e.g., biotite, feldspar), mature sediments or recycled deposits with abundant clay minerals typically yield a low index of compositional variability (ICV; $\left(\mathrm{Fe}_{2} \mathrm{O}_{3 \mathrm{~T}}+\mathrm{MgO}+\mathrm{CaO}+\mathrm{Na}_{2} \mathrm{O}+\right.$ $\mathrm{K}_{2} \mathrm{O}+\mathrm{Ti}_{2} \mathrm{O} / / \mathrm{Al}_{2} \mathrm{O}_{3}$ ) values, while immature sediments with few clay minerals tend to show high ICV values (Cox et al. 1995). In this study, the analyzed samples have high ICV values of 1.06-1.78 (fig. 6b), much higher than that (0.85) of PAASs (Taylor and McLennan 1985), suggesting that the samples were weakly weathered immature sediments. This agrees with the dominance of angular to subangular detrital grains (feldspar, quartz, and lithic fragment) in the samples. In particular, the
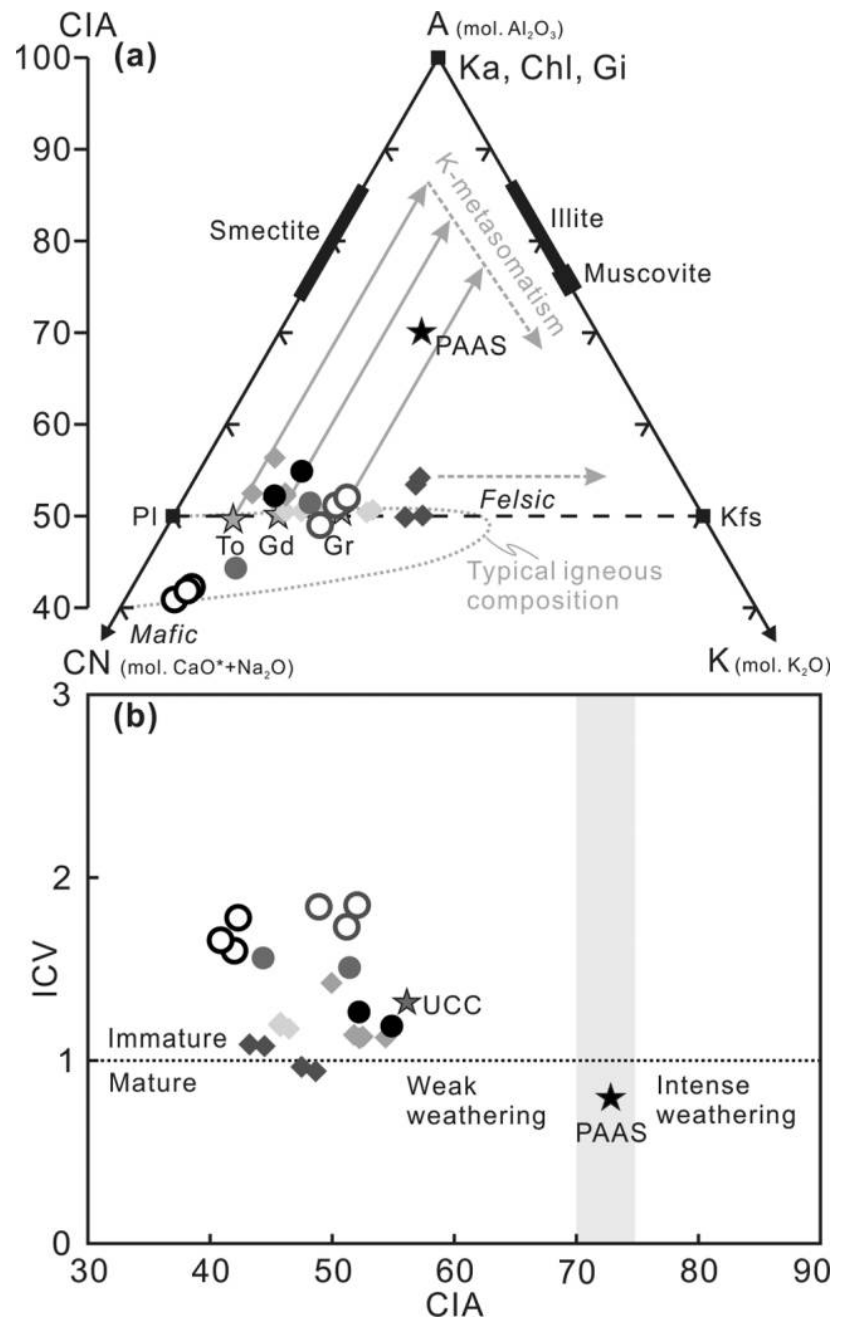

Figure 6. Ternary A-CN-K diagram (Nesbitt and Young 1984,$1989 ;$ a) and index of compositional variability (ICV)-versus-chemical index of alteration (CIA) diagram (Cox et al. 1995; b) for the Permian sandstones from the Eastern Tianshan. Data for post-Archean average shales (PAAS) are from Taylor and McLennan (1985), with those for tonalite (To), granodiorite $(\mathrm{Gd})$, and granite $(\mathrm{Gr})$ from Condie (1993). Symbols are as in figure 4 . Chl = chlorite, $\mathrm{Gi}=$ gibbsite, $\mathrm{Ka}=$ kaolinite, $\mathrm{Kf}$ s $=\mathrm{K}$-feldspar; $\mathrm{Pl}=$ plagioclase. A color version of this figure is available online.

Xingxingxia samples have ICV values (1.06-1.18) lower than those (1.27-1.78) of the other samples, in accordance with their higher $\mathrm{Al}_{2} \mathrm{O}_{3}$ contents and CIA values, which is probably a result of a higher fraction of clay minerals in the Xingxingxia samples, as supported by the presence of sericite in the two samples (fig. $3 g, 3 h$ ).

Moreover, intense weathering typically results in a significant increase in the $\mathrm{Rb} / \mathrm{Sr}$ ratio of sediments (McLennan et al. 1993). The Shaquanzi and 
Yamansu samples have very low $\mathrm{Rb} / \mathrm{Sr}$ ratios of $0.12-0.44$, lower than or comparable to that $(0.26)$ of UCC (Rudnick and Gao 2003), further testifying to a weak weathering in their sources. The relatively higher $\mathrm{Rb} / \mathrm{Sr}$ ratios of $0.69-0.87$ in the Xingxingxia samples, along with their higher $\mathrm{Al}_{2} \mathrm{O}_{3}$ and CIA but lower ICV values, indicate stronger, but still weak, source weathering.

Silicification and K-metasomatism are the two most important postdepositional alterations, typically resulting in increases of $\mathrm{Si}$ and $\mathrm{K}$ as well as decreases in $\mathrm{Ca}, \mathrm{Mg}$, and $\mathrm{Na}$ (minor $\mathrm{Fe}$ and $\mathrm{Sr}$ ) in the sediments (Cullers 1994, 1995). Each of the analyzed samples shows limited variations in the $\mathrm{SiO}_{2} / \mathrm{Al}_{2} \mathrm{O}_{3}$ ratio, suggesting weak silicification. In addition, the samples do not show obvious K-metasomatism trends in the A-CN-K $\left(\mathrm{Al}_{2} \mathrm{O}_{3}-\mathrm{CaO}^{*}+\mathrm{Na}_{2} \mathrm{O}-\mathrm{K}_{2} \mathrm{O}\right)$ diagram (fig. $6 a$; after Nesbitt and Young 1984, 1989), indicating negligible K-metasomatism.

Sedimentary Sorting and Recycling. Sedimentary sorting and recycling can influence the chemical compositions of sediments by selective enrichment of heavy minerals (e.g., monazite and zircon). For instance, slight enrichment of monazite may result in a significant increase in the $\mathrm{Gd}_{\mathrm{N}} / \mathrm{Yb}_{\mathrm{N}}$ ratio (typically $>2.0$ ) of sediments (Cullers 1988; McLennan et al. 1990, 1993), and enrichment of zircon can lead to high $\mathrm{Zr}$ and $\mathrm{Zr} / \mathrm{Sc}$ values of sediments (McLennan 1989; McLennan and Taylor 1991; McLennan et al. 1993; Cullers 1994). The Permian sandstones have low $\mathrm{Gd}_{\mathrm{N}} / \mathrm{Yb}_{\mathrm{N}}$ ratios of $1.20-1.53$ that are within the range (1.0-2.0) of most upper-crustal rocks (McLennan et al. 1993), indicative of faint enrichment of monazite. In addition, they have low $\mathrm{Zr}$ concentrations (99-225 ppm) and plot parallel to the magmatic trend in the Th/Sc-versus-Zr/Sc diagram /fig. 7a; McLennan et al. 1993), suggesting insignificant zircon enrichment.

Sedimentary sorting and recycling increase the textural maturity of sediments, resulting in an increase in the content of quartz, an elevation in the $\mathrm{SiO}_{2} / \mathrm{Al}_{2} \mathrm{O}_{3}$ ratio, and decreases in the contents of most trace elements (McLennan et al. 1993). In addition, successive sedimentary recycling can lead to a gradual increase in the $\mathrm{Th} / \mathrm{U}$ ratio of sediments because of the different solubilities of $U$ and $T h$ in oxidized conditions (McLennan and Taylor 1980). The Xingxingxia and Shaquanzi samples have low $\mathrm{Th} / \mathrm{U}$ ratios of $2.67-3.77$ (fig. $7 b$ ) that are lower than the typical values (3.89 and 4.5-5.5, respectively) of UCC (Rudnick and Gao 2003) and PAASs (McLennan and Taylor 1980), indicating a simple recycling history for the samples, consistent with their low $\mathrm{SiO}_{2} /$ $\mathrm{Al}_{2} \mathrm{O}_{3}$ ratios (4.51-5.82, except $\left.13 \mathrm{XX} 8 \mathrm{E}\right)$ but high
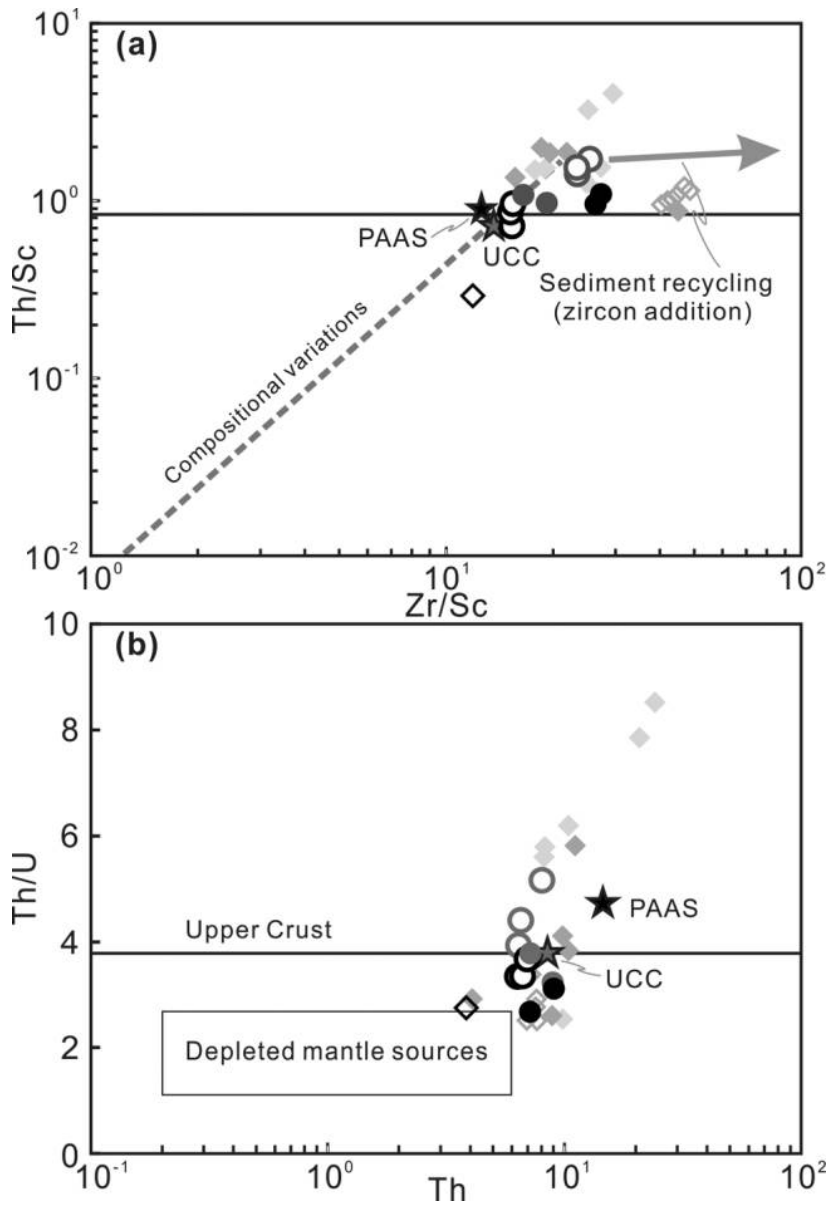

Figure 7. Th/Sc-versus-Zr/Sc $(a)$ and Th/U-versus-Th (b) diagrams (McLennan et al. 1993) for the Permian sandstones from the Eastern Tianshan. Trace elements are plotted in ppm. Symbols are as in figure 4. PAAS = post-Archean average shales; UCC = upper continental crust. A color version of this figure is available online.

¿REE contents (71.8-141.1 ppm). In contrast, the Yamansu samples have relatively higher $\mathrm{Th} / \mathrm{U}$ (3.935.16) and $\mathrm{SiO}_{2} / \mathrm{Al}_{2} \mathrm{O}_{3}(6.30-6.57)$ ratios but lower SREE (77.1-86.8 ppm) contents, probably reflecting more involvement of recycled components in the samples, consistent with the recent detrital zircon study revealing a very high content (ca. $45 \%$ ) of Precambrian detrital zircons in the samples (Zhang et al. 2016c).

In summary, most samples in this study are compositionally immature and have experienced insignificant postdepositional alternations. The Xingxingxia samples may have experienced a relatively stronger intensity of source weathering, as evidenced by their relatively higher CIA and $\mathrm{Rb} / \mathrm{Sr}$ but lower ICV values, and the Yamansu samples probably contain more recycled materials, as supported by their 
high $\mathrm{Th} / \mathrm{U}$ and $\mathrm{SiO}_{2} / \mathrm{Al}_{2} \mathrm{O}_{3}$ ratios but low $\sum \mathrm{REE}$ contents.

Source Nature and Provenance. In the A-CN-K diagram (fig. 6a), the Xingxingxia and Yamansu samples plot along the weathering trends of granodiorite and granite, respectively, suggestive of the dominance of intermediate to felsic rocks in their sources, whereas the Shaquanzi samples plot in the field of typical igneous rocks, possibly resulting from mixing between intermediate/mafic and felsic compositions (McLennan et al. 1993). In addition, in the F1F2 and F3-F4 discriminant-function diagrams (fig. 8; after Roser and Korsch 1988), the Yamansu and Xingxingxia samples dominantly plot in the felsic igneous provenance, and the Shaquanzi samples plot in the intermediate or felsic igneous provenance. A similar conclusion can be found in the $\mathrm{K}_{2} \mathrm{O}$-versus- $\mathrm{Rb}$ diagram (fig. $9 a$; after Floyd et al. 1989), in which most of the samples plot along the magmatic trend of intermediate to acidic rocks. Moreover, the Xingxingxia samples fall in the field of acidic arc source, with the Shaquanzi and Yamansu samples dominantly plotted in the field of mixed felsic and basic sources in the La/Th-versus-Hf diagram (fig. 9b; after Floyd and Leveridge 1987). Furthermore, the samples mostly plot close to the felsic volcanic rocks in the Co/Th-versus-La/Sc diagram (fig. $9 c$; after Kelemen et al. 2003).

The REE contents and patterns of sediments can be used to characterize the nature of their sources (Nance and Taylor 1976; Chaudhuri and Cullers 1979; Gao et al. 1998). Generally, mafic rocks con- tain low abundances of REEs with weak to negligible $\mathrm{Eu}$ anomalies, whereas felsic rocks have relatively higher contents of REEs with obvious negative Eu anomalies (Cullers et al. 1997). The Xingxingxia samples are characterized by relatively high $\sum$ REE contents (113.6-141.1 ppm) with UCC-like REE patterns and strong negative $\mathrm{Eu}$ anomalies $(\delta \mathrm{Eu}=0.70$ $0.74)$, indicating the dominance of felsic rocks in their sources. The Yamansu samples have lower $\sum$ REE contents of 77.1-86.8 ppm with UCC-like but lower REE patterns and obvious negative Eu anomalies $(\delta \mathrm{Eu}=0.70-0.75)$, indicative of a significant proportion of felsic rocks in the sources. The low REE contents of the Yamansu samples can be attributed to quartz dilution (Taylor and McLennan 1985), as supported by their relatively high $\mathrm{SiO}_{2}$ contents (69.3-70.8 wt\%). The Shaquanzi samples show variable $\sum$ REE contents of 71.8-111.6 ppm with moderate to negligible negative Eu anomalies $(\delta \mathrm{Eu}=0.70$ 0.99 ), suggesting the involvement of intermediate/ mafic components in the sources. The above considerations are further supported by their trace-element contents and distributions (fig. 5), with the Xingxingxia samples exhibiting distributions of trace elements nearly identical to that of UCC, the Yamansu samples showing UCC-like but lower patterns, and the Shaquanzi samples displaying mixed signatures situated between those of LCC and UCC.

The above lines of evidence suggest that detrital materials of the Permian sandstones were mainly derived from intermediate to felsic rocks, with the Shaquanzi samples probably containing more inter-
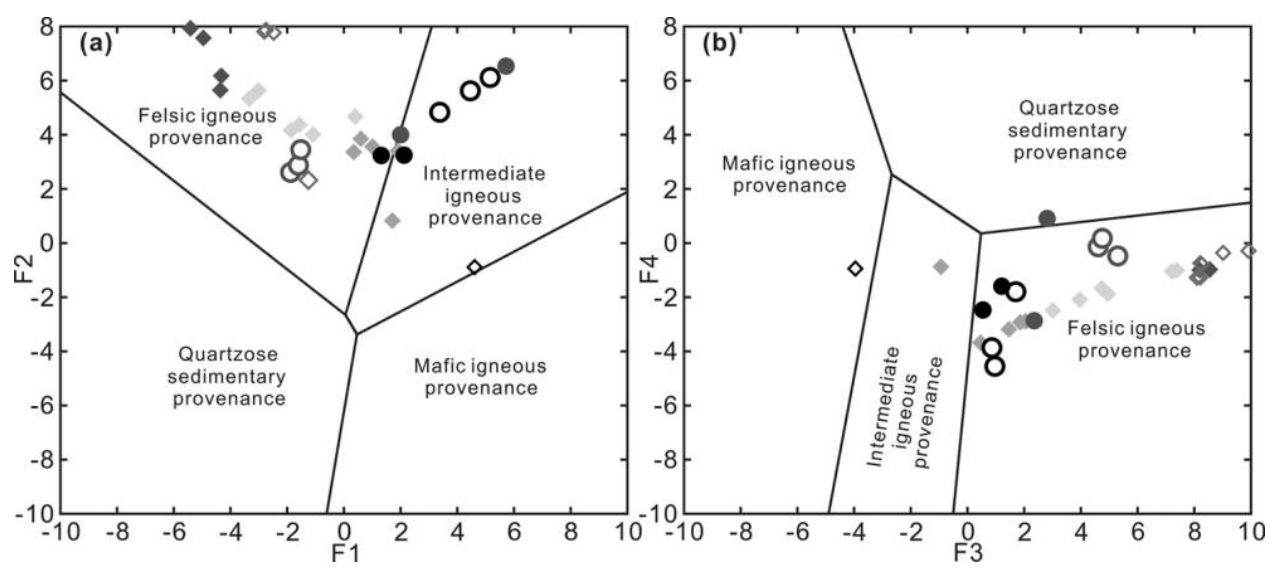

Figure 8. F1-F2 $(a)$ and F3-F4 $(b)$ sedimentary-provenance discriminant-function diagrams (Roser and Korsch 1988) for the Permian sandstones from the Eastern Tianshan. $\mathrm{F} 1=-1.773 \times \mathrm{TiO}_{2}+0.607 \times \mathrm{Al}_{2} \mathrm{O}_{3}+0.76 \times \mathrm{Fe}_{2} \mathrm{O}_{3}-1.5 \times$ $\mathrm{MgO}+0.616 \times \mathrm{CaO}+0.509 \times \mathrm{Na}_{2} \mathrm{O}-1.224 \times \mathrm{K}_{2} \mathrm{O}-9.09 ; \mathrm{F} 2=0.445 \times \mathrm{TiO}_{2}+0.07 \times \mathrm{Al}_{2} \mathrm{O}_{3}-0.25 \times \mathrm{Fe}_{2} \mathrm{O}_{3}-$ $1.142 \times \mathrm{MgO}+0.438 \times \mathrm{CaO}+1.475 \times \mathrm{Na}_{2} \mathrm{O}+1.426 \times \mathrm{K}_{2} \mathrm{O}-6.861 ; \mathrm{F} 3=30.638 \times \mathrm{TiO}_{2} / \mathrm{Al}_{2} \mathrm{O}_{3}-12.541 \times \mathrm{Fe}_{2} \mathrm{O}_{3} /$ $\mathrm{Al}_{2} \mathrm{O}_{3}+7.329 \times \mathrm{MgO} / \mathrm{Al}_{2} \mathrm{O}_{3}+12.031 \times \mathrm{Na}_{2} \mathrm{O} / \mathrm{Al}_{2} \mathrm{O}_{3}+35.402 \times \mathrm{K}_{2} \mathrm{O} / \mathrm{Al}_{2} \mathrm{O}_{3}-6.382 ; \mathrm{F} 4=56.5 \times \mathrm{TiO}_{2} / \mathrm{Al}_{2} \mathrm{O}_{3}-$ $10.879 \times \mathrm{Fe}_{2} \mathrm{O}_{3} / \mathrm{Al}_{2} \mathrm{O}_{3}+30.875 \times \mathrm{MgO} / \mathrm{Al}_{2} \mathrm{O}_{3}-5.404 \times \mathrm{Na}_{2} \mathrm{O} / \mathrm{Al}_{2} \mathrm{O}_{3}+11.112 \times \mathrm{K}_{2} \mathrm{O} / \mathrm{Al}_{2} \mathrm{O}_{3}-3.89$; major oxides are in $\mathrm{wt} \%$ (water free). Symbols are as in figure 4. A color version of this figure is available online. 

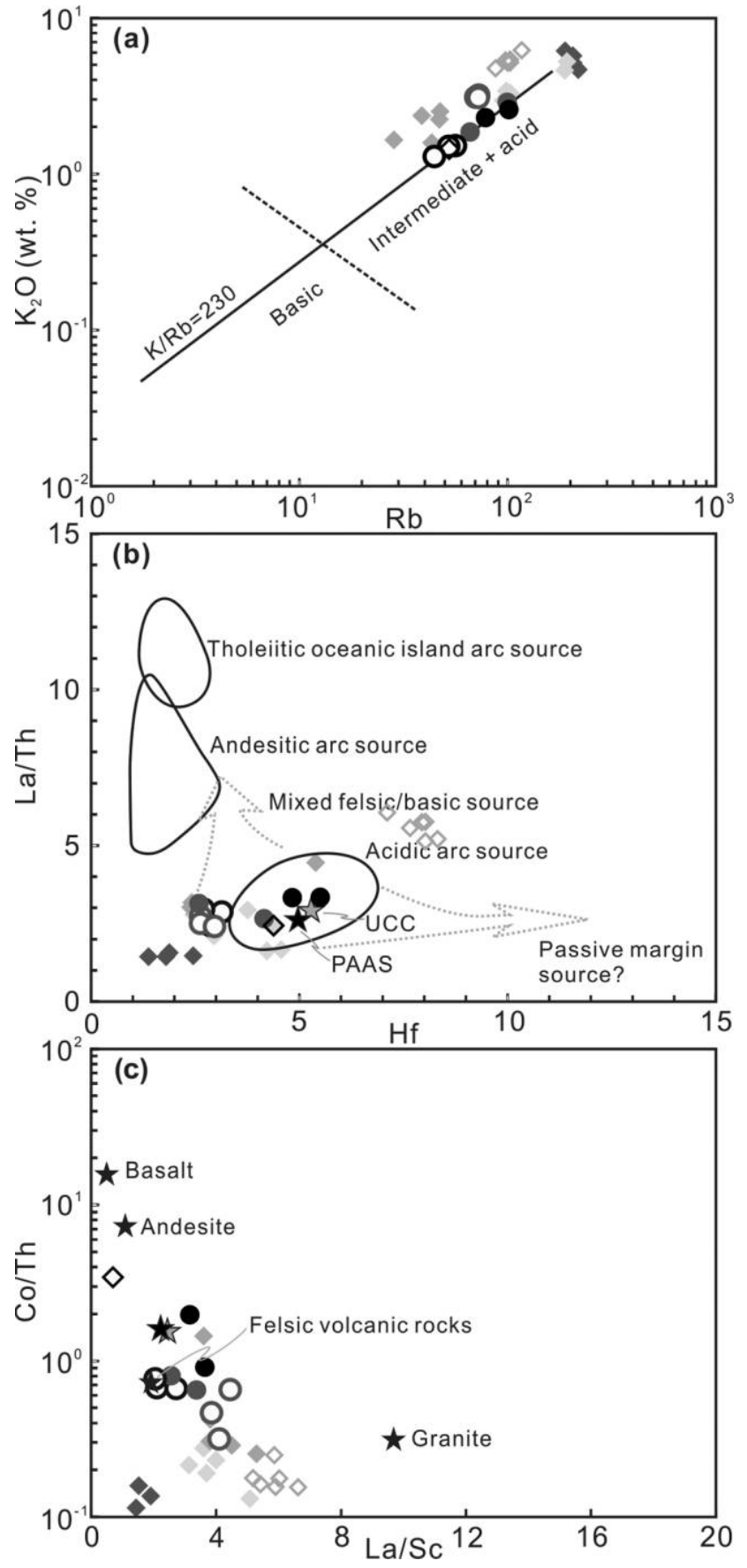

Figure 9. $\mathrm{K}_{2} \mathrm{O}$-versus- $\mathrm{Rb}$ (Floyd et al. 1989; a), La/Thversus-Hf (Floyd and Leveridge 1987; b), and Co/Thversus-La/Sc (Kelemen et al. 2003; c) diagrams for the Permian sandstones from the Eastern Tianshan. Major oxides are in units of $w t \%$ (water free), with trace elements plotted in ppm. Symbols are as in figure 4. PAAS = post-Archean average shales; UCC = upper continental crust. A color version of this figure is available online.

mediate/mafic components. As shown in figure 10, previous detrital zircon studies have shown that the samples are predominantly composed of Paleo- zoic components (peaks at ca. 460-430, 340-290, and $265 \mathrm{Ma}$ ), with the Yamansu sample (13YM3C) exhibiting a much higher content (ca. $45 \%$ ) of Precambrian detrital zircons (Zhang et al. 2015b, 2016c). Accordingly, the geochemical compositions of $\mathrm{Pa}$ leozoic intermediate to felsic rocks near the Permian sandstones, including ca. $450 \mathrm{Ma}$ I-type granitoids and S-type granites (Zhang et al. 2016a), ca. $320 \mathrm{Ma}$ subduction-related I-type granitoids (Zhang et al. 2015a) from the CTS block, and ca. 337-330 Ma island arc granites (Zhang et al. 2017) and andesite (Hou et al. 2005) in the NTS belt (see figs. 1, 2 for sample locations), are plotted in figs. 4-12 and roughly overlap those of Permian sandstones. Therefore, we suggest that the selected Paleozoic magmatic rocks may approximate the actual source rocks for the Permian strata in the NTS belt. It deserves mention that the detrital materials for the Xingxingxia samples in the STS belt may have been derived mostly from the southern margin of the CTS block, as the CTS block was most probably a topographic highland in the Permian (Zhang et al. 2015b, 2016c).

Inconsistent Tectonic-Setting Discriminations and Explanations. Our results show that tectonic-setting discrimination using geochemical data from the Permian sandstones yields inconsistent results. In the $\mathrm{K} 2 \mathrm{O} / \mathrm{Na}_{2} \mathrm{O}$-versus- $\mathrm{SiO}_{2}, \mathrm{TiO}_{2}$-versus- $\left(\mathrm{Fe}_{2} \mathrm{O}_{3 \mathrm{~T}}+\mathrm{MgO}\right)$, and $\mathrm{Al}_{2} \mathrm{O}_{3} / \mathrm{SiO}_{2}$-versus- $\left(\mathrm{Fe}_{2} \mathrm{O}_{3 \mathrm{~T}}+\mathrm{MgO}\right)$ discrimination diagrams (fig. 11; after Bhatia 1983; Roser and Korsch 1986), the Shaquanzi and Xingxingxia samples dominantly plot in or adjacent to the ACM field, whereas they mostly plot in the continental island arc (CIA) field in the Ti/Zr-versus-La/Sc, Sc-La-Th, Sc-Th-Zr/10, and $\mathrm{Zr} / 10-\mathrm{Th}-\mathrm{Co}$ discrimination diagrams (fig. 12; after Bhatia and Crook 1986). In contrast, the Yamansu samples mainly plot in or adjacent to the PM field in the above discrimination diagrams (figs. 11, 12).

As mentioned above, the Permian strata in the Eastern Tianshan were most probably deposited in a postcollisional extension tectonic setting (Chen and Shu 2010; Yuan et al. 2010; Chen et al. 2011; Wang et al. 2014; Ma et al. 2015), which is difficult to assign to the ACM, CIA, or PM settings. We suggest that the above inconsistent tectonic-setting discriminations are probably caused by a significant variability in the proportions of different source rocks that have distinct geochemical compositions, with evidence from the following observations.

First, the Shaquanzi samples from the NTS belt were collected from different layers of a continuous sedimentary sequence $(<20 \mathrm{~m}$ thick $)$, and thus they must have been formed in the same tectonic setting. Detrital zircon studies of the samples reveal 

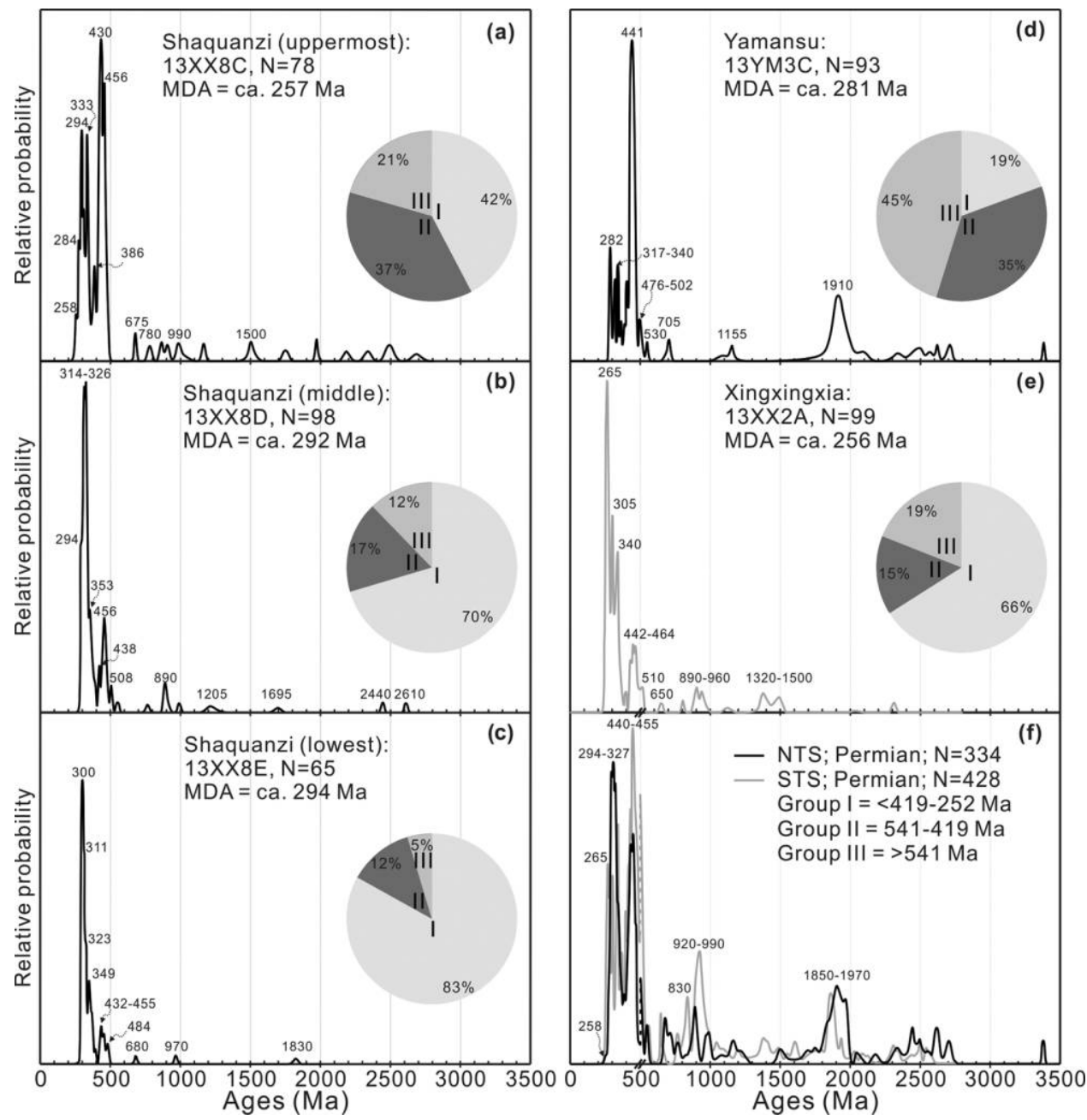

Figure 10. Detrital zircon age profiles for the Shaquanzi, Yamansu, and Xingxingxia sandstones, combined with compiled age profiles for Permian strata in the North Tianshan (NTS) and South Tianshan (STS) belts. Data are compiled from Chen et al. (2014) and Zhang et al. $(2015 b, 2016 c)$. MDA = maximum depositional age. A color version of this figure is available online.

that the source materials were mainly derived from Precambrian basement and early Paleozoic magmatic rocks in the CTS block as well as DevonianCarboniferous island arc-related juvenile magmatism in the NTS belt (Zhang et al. 2016c). As shown in figure $10 a-10 c$, systematic variations in the proportions of different source materials can be observed from the lower samples 13XX8E and 13XX8D to the upper samples $13 \mathrm{XX} 8 \mathrm{C}-13 \mathrm{XX} 8 \mathrm{~A}$, such as major increases in the proportions of Precambrian (group III) and early Paleozoic (group II) components and significant decreases (from $83 \%-70 \%$ to $42 \%$ ) in the proportions of the late Paleozoic (group I) component. These dramatic changes in the contents of different sources probably led to significant (roughly linear) variations in the geochemical compositions of the samples, such as increases in $\mathrm{Sr}, \mathrm{Sr} / \mathrm{Y}$, and $\mathrm{Sc} / \mathrm{Th}$ and decreases in $\mathrm{Cr}, \mathrm{Ni}, \mathrm{Rb}, \mathrm{Nb}, \mathrm{Cs}, \mathrm{REE}, \mathrm{Ta}, \mathrm{Th}, \mathrm{La} /$ $\mathrm{Sc}, \mathrm{Cr} / \mathrm{Th}, \mathrm{Rb} / \mathrm{Sr}, \mathrm{Zr} / \mathrm{Sc}$, and $\mathrm{Th} / \mathrm{Sc}$ values from the older samples $13 \mathrm{XX} 8 \mathrm{E}$ and $13 \mathrm{XX} 8 \mathrm{D}$ to the younger samples 13XX8C-13XX8A. More importantly, in the tectonic-setting discrimination diagrams, the samples exhibit roughly linear variations from CIA to ACM settings and plot between ca. $337 \mathrm{Ma}$ andesite from the NTS belt (Hou et al. 2005) and ca. 450$320 \mathrm{Ma}$ subduction-related I-type granitoids from the CTS block (Zhang et al. 2015a, 2016a). Therefore, it is reasonable to assume that the ACM affinities of the samples are possibly inherited from the Paleozoic subduction-related magmatism in the CTS block, with their CIA signatures likely inherited from the island arc materials in the NTS belt.

Second, the Yamansu samples were also collected from the Permian strata in the NTS belt, sharing 

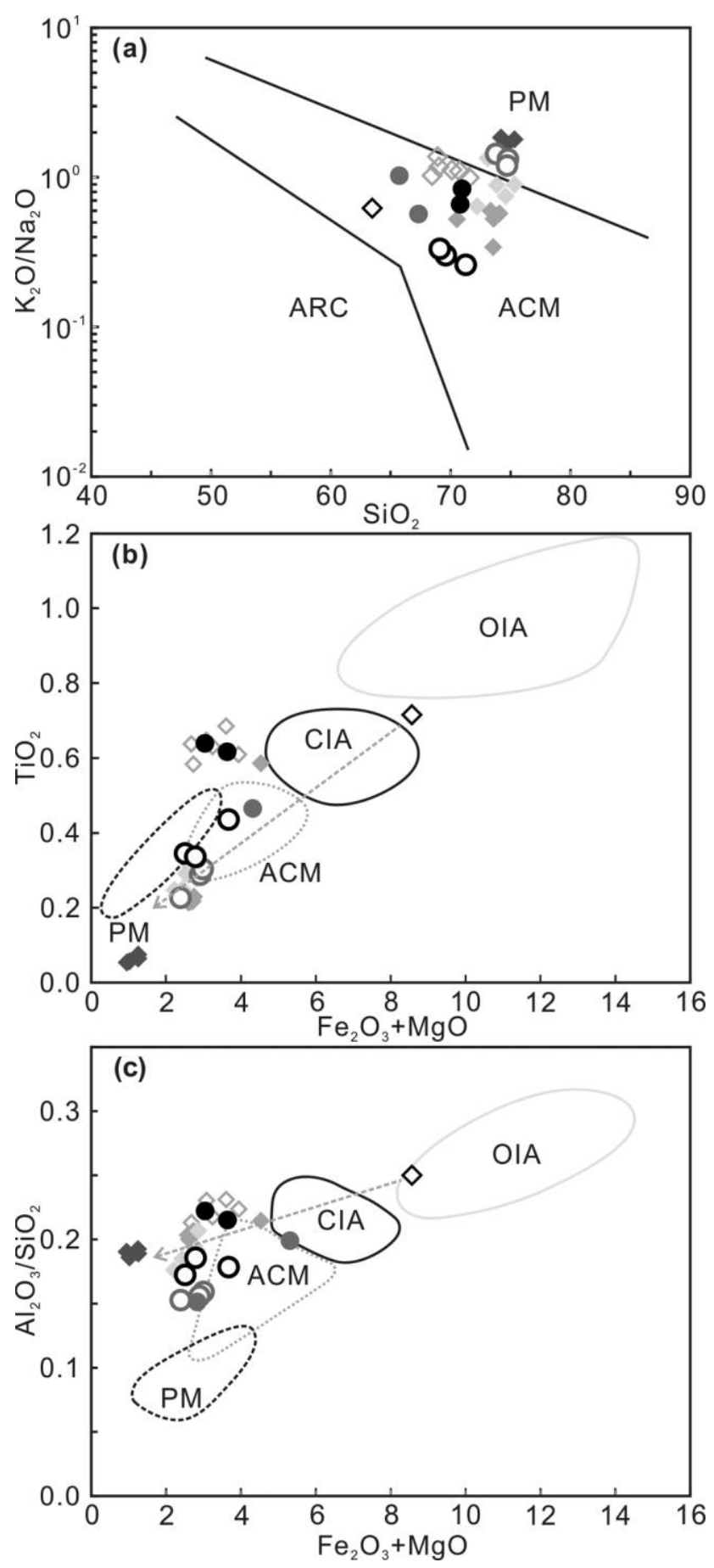

Figure 11. $\mathrm{K}_{2} \mathrm{O} / \mathrm{Na}_{2} \mathrm{O}$-versus- $\mathrm{SiO}_{2} \quad(a)$, $\mathrm{TiO}_{2}$-versus$\left(\mathrm{Fe}_{2} \mathrm{O}_{3 \mathrm{~T}}+\mathrm{MgO}\right)(b)$, and $\mathrm{Al}_{2} \mathrm{O}_{3} / \mathrm{SiO}_{2}$-versus- $\left(\mathrm{Fe}_{2} \mathrm{O}_{3 \mathrm{~T}}+\right.$ $\mathrm{MgO}$ (c) diagrams (Bhatia 1983; Bhatia and Crook 1986; Roser and Korsch 1986) for the Permian sandstones from the Eastern Tianshan. The dashed arrows indicate variations from North Tianshan andesite to Central Tianshan Paleozoic subduction-related granitoids. Symbols are as in figure 4. $\mathrm{ACM}=$ active continental margin; $\mathrm{ARC}, \mathrm{OIA}=$ oceanic island arc; $\mathrm{CIA}=$ continental island arc; $\mathrm{PM}=$ passive margin. A color version of this figure is available online. comparable depositional ages with the Shaquanzi samples 13XX8E and 13XX8D, which indicates that they should have been formed in the same depositional tectonic setting (most probably postcollisional extension). However, as revealed by their detrital zircon age profiles (Zhang et al. 2016c), the Yamansu samples contain a very high content (ca. $45 \%$ ) of Precambrian materials, much higher than those $15 \%-$ $21 \%$ ) of the Shaquanzi samples (fig. 10a-10d), consistent with their geochemical compositions revealing more involvement of recycled materials. Therefore, it is plausible that such a high content of Precambrian materials in the Yamansu samples possibly leads to the relatively high $\mathrm{SiO}_{2} / \mathrm{Al}_{2} \mathrm{O}_{3}, \mathrm{La} / \mathrm{Sc}, \mathrm{Zr} / \mathrm{Sc}$, $\mathrm{Th} / \mathrm{Sc}, \mathrm{Th} / \mathrm{U}$, and $\mathrm{Rb} / \mathrm{Sr}$ but low Sc, Cr, Co, Ni, and $\delta$ Eu values of the samples, which give rise to the PM affinities in the tectonic-setting discrimination diagrams (figs. 11, 12).

Third, Late Permian Xingxingxia samples 13XX2A and $13 \mathrm{XX} 2 \mathrm{~B}$, from the STS belt, share a detrital zircon age profile, particularly the contents of Precambrian to late Paleozoic zircons, comparable to that of Early Permian Shaquanzi sample 13XX8D, from the NTS belt (fig. 10b, 10e; Zhang et al. 2015b, 2016c). Moreover, the Xingxingxia samples have geochemical compositions, such as relatively high contents of $\mathrm{Rb}, \mathrm{Zr}, \mathrm{Y}, \mathrm{Cs}, \mathrm{Th}, \mathrm{U}$, and REEs, similar to those of sample $13 \mathrm{XX} 8 \mathrm{D}$, and they are further plotted very close to each other in the discrimination diagrams (figs. 11, 12).

The above observations strongly suggest that the inconsistent results derived from geochemical discrimination diagrams for tectonic settings of the Permian sandstones most probably reflect different proportions of the geochemically distinct source materials. This study highlights that the geochemical compositions of sandstones can be significantly influenced not only by source compositions but also by the proportions of different sources, implying that geochemical compositions of sediments from the same depositional tectonic setting or even within a continuous sequence can vary significantly because of changes in the proportions of different sources, when common bulk-rock geochemical tectonicsetting discrimination diagrams should be applied with great caution.

\section{Conclusions}

Whole-rock major- and trace-element analysis of Permian sandstones from the Eastern Tianshan led to the following conclusions:

1. The samples are characterized by low chemical index of alteration values but high index of com- 


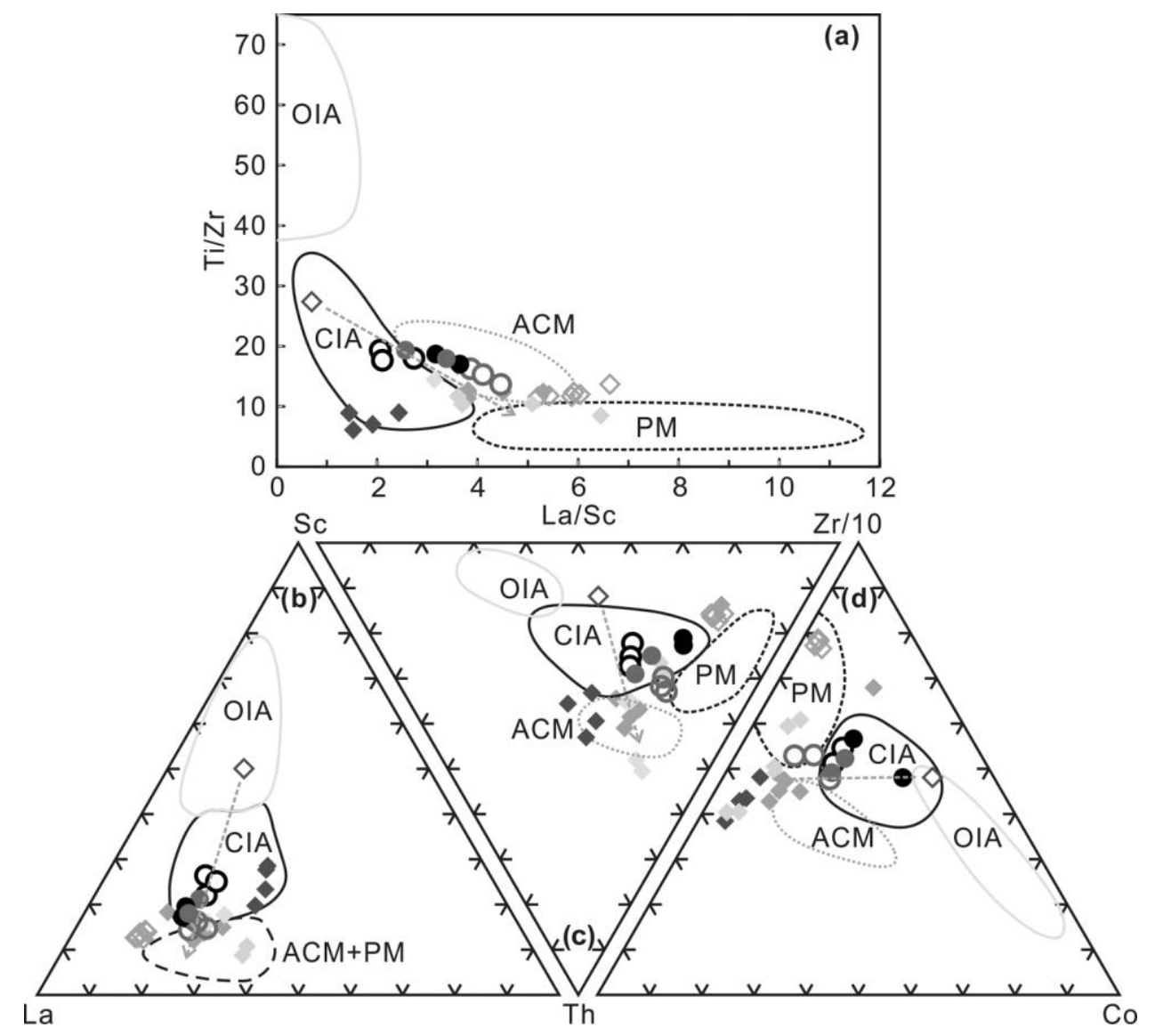

Figure 12. Ti/Zr-versus-La/Sc $(a)$, Sc-La-Th $(b)$, Th-Sc-Zr/10 $(c)$, and $\mathrm{Zr} / 10-\mathrm{Th}-\mathrm{Co}(d)$ diagrams (Bhatia and Crook 1986) for the Permian sandstones from the Eastern Tianshan. Trace elements are plotted in ppm. The dashed arrows indicate variations from North Tianshan (NTS) andesite to Central Tianshan (CTS) Paleozoic subduction-related granitoids. Symbols are as in figure 4 . ACM = active continental margin; CIA = continental island arc; OIA = oceanic island arc; $\mathrm{PM}=$ passive margin. A color version of this figure is available online.

positional variability values, suggesting derivation mainly from compositionally immature sources with weak chemical weathering. The samples have relatively low $\mathrm{Zr}$ concentrations and $\mathrm{Gd}_{\mathrm{N}} / \mathrm{Yb}_{\mathrm{N}}$ ratios, indicating insignificant zircon and monazite enrichment. They exhibit UCC-like REE patterns with obvious to negligible negative Eu anomalies, underlining the dominance of intermediate to felsic rocks in the sources.

2. Numerous previous investigations have demonstrated that the Permian strata in the Eastern Tianshan were most probably deposited in a postcollisional extension tectonic setting. However, tectonic-setting discrimination diagrams using geochemical compositions of the Permian sandstones yield inconsistent results varying from ACM or CIA to PM settings.

3. Combining our findings with those of previous detrital zircon studies, we suggest that variable proportions of different source rocks lead to the different tectonic-setting discrimination results.

\section{A C K N O W LED G MENTS}

We very much appreciate the valuable comments from the reviewer, W. Xiao, and the editor, D. B. Rowley. This study was financially supported by National Natural Science Foundation of China (NSFC) Project 41190075, "Final Closure of the Paleo-Asian Ocean and Reconstruction of East Asian Blocks in Pangea," which is the fifth research project of NSFC Major Program 41190070, "Reconstruction of East Asian Blocks in Pangea"; by Hong Kong Research Grants Council General Research Fund grants 7063/ $13 \mathrm{P}$ and 17301915; and by NSFC General Projects 41230207 and 41390441, as well as University of Hong Kong Seed Funding Programmes for Basic Research 201409176061 and 201511159120. 


\section{R E F E R E N C E S C I T E D}

Allen, M. B.; Windley, B. F.; and Chi, Z. 1993. Paleozoic collisional tectonics and magmatism of the Chinese Tien-Shan, Central-Asia. Tectonophysics 220:89115.

Armstrong-Altrin, J. S., and Verma, S. P. 2005. Critical evaluation of six tectonic setting discrimination diagrams using geochemical data of Neogene sediments from known tectonic settings. Sediment. Geol. 177:115-129.

Bhatia, M. R. 1983. Plate tectonics and geochemical composition of sandstones. I. Geol. 91:611-627.

Bhatia, M. R., and Crook, K. A. W. 1986. Trace element characteristics of graywackes and tectonic setting discrimination of sedimentary basins. Contrib. Mineral. Petrol. 92:181-193.

Charvet, J.; Shu, L. S.; and Laurent-Charvet, S. 2007. Paleozoic structural and geodynamic evolution of eastern Tianshan (NW China): welding of the Tarim and Junggar plates. Episodes 30:162-186.

Charvet, J.; Shu, L. S.; Laurent-Charvet, S.; Wang, B.; Faure, M.; Cluzel, D.; Chen, Y.; and Jong, K. D. 2011. Palaeozoic tectonic evolution of the Tianshan belt, NW China. Sci. China Earth Sci. 54:166-184.

Chaudhuri, S., and Cullers, R. L. 1979. The distribution of rare-earth elements in deeply buried Gulf Coast sediments. Chem. Geol. 24:327-338.

Chen, C. M.; Lu, H. F.; Jia, D.; Cai, D. S.; and Wu, S. M. 1999. Closing history of the southern Tianshan oceanic basin, western China: an oblique collisional orogeny. Tectonophysics 302:23-40.

Chen, X. J., and Shu, L. S. 2010. Features of the postcollisional tectono-magmatism and geochronological evidence in the Harlik Mountains, Xinjiang. Acta Petrol. Sin. 26:3057-3064 (in Chinese with English abstract).

Chen, X. J.; Shu, L. S.; and Santosh, M. 2011. Late Paleozoic post-collisional magmatism in the eastern Tianshan Belt, northwest China: new insights from geochemistry, geochronology and petrology of bimodal volcanic rocks. Lithos 127:581-598.

Chen, X. J.; Shu, L. S.; Santosh, M.; and Xu, Z. Q. 2014. The provenance and tectonic affinity of the Paleozoic meta-sedimentary rocks in the Chinese Tianshan belt: new insights from detrital zircon U-Pb geochronology and $\mathrm{Hf}$ isotope analysis. I. Asian Earth Sci. 94:12-27.

Condie, K. C. 1993. Chemical composition and evolution of the upper continental crust: contrasting results from surface samples and shales. Chem. Geol. 104:1-37.

Cox, R.; Lowe, D. R.; and Cullers, R. L. 1995. The influence of sediment recycling and basement composition on evolution of mudrock chemistry in the southwestern United States. Geochim. Cosmochim. Acta 59:2919-2940.

Cullers, R. L. 1988. Mineralogical and chemical changes of soil and stream sediment formed by intense weath- ering of the Danburg granite, Georgia, USA. Lithos 21:301-314.

- 1994. The controls on the major and trace element variation of shales, siltstones, and sandstones of Pennsylvanian-Permian age from uplifted continental blocks in Colorado to platform sediment in Kansas, USA. Geochim. Cosmochim. Acta 58:4955-4972.

1995. The controls on the major- and traceelement evolution of shales, siltstones and sandstones of Ordovician to Tertiary age in the Wet Mountains region, Colorado, U.S.A. Chem. Geol. 123:107-131.

Cullers, R. L.; Bock, B.; and Guidotti, C. 1997. Elemental distributions and neodymium isotopic compositions of Silurian metasediments, western Maine, USA: redistribution of the rare earth elements. Geochim. Cosmochim. Acta 61:1847-1861.

Cullers, R. L.; DiMarco, M. J.; Lowe, D. R.; and Stone, J. 1993. Geochemistry of a silicified, felsic volcaniclastic suite from the early Archaean Panorama Formation, Pilbara Block, Western Australia: an evaluation of depositional and post-depositional processes with special emphasis on the rare-earth elements. Precambrian Res. 60:99-116.

Dong, Y. P.; Zhang, G. W.; Neubauer, F.; Liu, X. M.; Hauzenberger, C.; Zhou, D. W.; and Li, W. 2011. Syn- and post-collisional granitoids in the Central Tianshan orogen: geochemistry, geochronology and implications for tectonic evolution. Gondwana Res. 20:568-581.

Eizenhöfer, P. R.; Zhao, G. C.; Zhang, J.; Han, Y. G.; Hou, W. Z.; Liu, D. X.; and Wang, B. 2015. Geochemical characteristics of the Permian basins and their provenances across the Solonker Suture Zone: assessment of net crustal growth during the closure of the Palaeo-Asian Ocean. Lithos 224:240-255.

Fedo, C. M.; Eriksson, K. A.; and Krogstad, E. J. 1996. Geochemistry of shales from the Archean ( 3.0 Ga) Buhwa Greenstone Belt, Zimbabwe: implications for provenance and source-area weathering. Geochim. Cosmochim. Acta 60:1751-1763.

Fedo, C. M.; Nesbitt, H. W.; and Young, G. M. 1995. Unraveling the effects of potassium metasomatism in sedimentary rocks and paleosols, with implications for paleoweathering conditions and provenance. Geology 23:921-924.

Floyd, P. A., and Leveridge, B. E. 1987. Tectonic environment of the Devonian Gramscatho basin, south Cornwall: framework mode and geochemical evidence from turbiditic sandstones. I. Geol. Soc. Lond. 144: 531-542.

Floyd, P. A.; Winchester, J. A.; and Park, R. G. 1989. Geochemistry and tectonic setting of Lewisian clastic metasediments from the Early Proterozoic Loch Maree Group of Gairloch, NW Scotland. Precambrian Res. 45:203-214. 
Gao, J.; Li, M. S.; Xiao, X. C.; Tang, Y. Q.; and He, G. Q. 1998. Paleozoic tectonic evolution of the Tianshan Orogen, northwestern China. Tectonophysics 287: 213-231.

Han, B. F.; Guo, Z. J.; Zhang, Z. C.; Zhang, L.; Chen, J. F.; and Song, B. 2010. Age, geochemistry, and tectonic implications of a late Paleozoic stitching pluton in the North Tian Shan suture zone, western China. Geol. Soc. Am. Bull. 122:627-640.

Han, B. F.; He, G. Q.; Wang, X. C.; and Guo, Z. J. 2011. Late Carboniferous collision between the Tarim and Kazakhstan-Yili terranes in the western segment of the South Tian Shan Orogen, Central Asia, and implications for the Northern Xinjiang, western China. Earth-Sci. Rev. 109:74-93.

Han, Y. G.; Zhao, G. C.; Cawood, P. A.; Sun, M.; Eizenhöfer, P. R.; Hou, W. Z.; Zhang, X. R.; and Liu, Q. 2016a. Tarim and North China cratons linked to northern Gondwana through switching accretionary tectonics and collisional orogenesis. Geology 44:95-98.

Han, Y. G.; Zhao, G. C.; Sun, M.; Eizenhöfer, P. R.; Hou, W. Z.; Zhang, X. R.; Liu, D. X.; and Wang, B. 2016b. Detrital zircon provenance constraints on the initial uplift and denudation of the Chinese western Tianshan after the assembly of the southwestern Central Asian Orogenic Belt. Sediment. Geol. 339:1-12.

Han, Y. G.; Zhao, G. C.; Sun, M.; Eizenhöfer, P. R.; Hou, W. Z.; Zhang, X. R.; Liu, D. X.; Wang, B.; and Zhang, G. W. 2015. Paleozoic accretionary orogenesis in the Paleo-Asian Ocean: insights from detrital zircons from Silurian to Carboniferous strata at the northwestern margin of the Tarim Craton. Tectonics 34:334-351.

Han, Y. G.; Zhao, G. C.; Sun, M.; Eizenhöfer, P. R.; Hou, W. Z.; Zhang, X. R.; Liu, Q.; Liu, D. X.; Wang, B.; and $\mathrm{Xu}$, B. 2016c. Late Paleozoic subduction and collision processes during the amalgamation of the Central Asian Orogenic Belt along the South Tianshan suture zone. Lithos 246:1-12.

Haughton, P. D. W. 1988. A cryptic Caledonian flysch terrane in Scotland. I. Geol. Soc. Lond. 145:685-703.

He, Z. Y.; Zhang, Z. M.; Zong, K. Q.; Xiang, H.; Chen, X. J.; and Xia, M. J. 2014. Zircon U-Pb and Hf isotopic studies of the Xingxingxia Complex from Eastern Tianshan (NW China): significance to the reconstruction and tectonics of the southern Central Asian Orogenic Belt. Lithos 190:485-499.

Hou, G. S.; Tang, H. F.; Liu, C. Q.; and Wang, Y. B. 2005. Geochronological and geochemical study on the wallrock of Tuwu-Yandong porphyry copper deposits, eastern Tianshan Mountains. Acta Petrol. Sin. 21:1729-1736.

Hu, A. Q.; Jahn, B. M.; Zhang, G. X.; Chen, Y. B.; and Zhang, Q. F. 2000. Crustal evolution and Phanerozoic crustal growth in northern Xinjiang: Nd isotopic evidence. Part I. Isotopic characterization of basement rocks. Tectonophysics 328:15-51.
Hu, A. Q.; Wei, G. J.; Deng, W. F.; Zhang, J. B.; and Chen, L. L. 2006. 1.4 Ga SHRIMP U-Pb age for zircons of granodiorite and its geological significance from the eastern segment of the Tianshan Mountains, Xinjiang, China. Geochimica 35:333-345.

Hu, A. Q.; Zhang, G. X.; Zhang, Q. F.; and Chen, Y. B. 1998. Constraints on the age of basement and crustal growth in Tianshan Orogen by $\mathrm{Nd}$ isotopic composition. Sci. China Ser. D 41:648-657.

Kelemen, P. B.; Hanghøj, K.; and Greene, A. R. 2003. One view of the geochemistry of subduction-related magmatic arcs, with an emphasis on primitive andesite and lower crust. In Rudnick, R. L., ed. The crust. Vol. 3 of Holland, H. H., and Turekian, K. K., eds. Treatise on geochemistry. Oxford, Elsevier-Pergamon, p. 593-659.

Lei, R. X.; Wu, C. Z.; Chi, G. X.; Gu, L. X.; Dong, L. H.; Qu, X.; Jiang, Y. H.; and Jiang, S. Y. 2013. The Neoproterozoic Hongliujing A-type granite in Central Tianshan (NW China): LA-ICP-MS zircon U-Pb geochronology, geochemistry, Nd-Hf isotope and tectonic significance. I. Asian Earth Sci. 74:142-154.

Li, W. Q.; Ma, H. D.; Wang, R.; Wang, H.; and Xia, B. 2008. SHRIMP dating and Nd-Sr isotopic tracing of Kangguertage ophiolite in eastern Tianshan, Xinjiang. Acta Petrol. Sin. 24:773-780 (in Chinese with English abstract).

Liu, Q.; Zhao, G. C.; Sun, M.; Eizenhöfer, P. R.; Han, Y. G.; Hou, W. Z.; Zhang, X. R.; Wang, B.; Liu, D. X.; and $\mathrm{Xu}, \mathrm{B} .2015$. Ages and tectonic implications of Neoproterozoic ortho- and paragneisses in the Beishan Orogenic Belt, China. Precambrian Res. 266:551-578.

Ma, R. S.; Shu, L. S.; and Sun, J. Q. 1997. Tectonic evolution and metallogeny of eastern Tianshan Mountains. Beijing, Geological Publishing House.

Ma, X. X.; Shu, L. S.; and Meert, J. G. 2015. Early Permian slab breakoff in the Chinese Tianshan belt inferred from the post-collisional granitoids. Gondwana Res. 27:228-243.

Ma, X. X.; Shu, L. S.; Meert, J. G.; and Li, J. Y. 2014. The Paleozoic evolution of Central Tianshan: geochemical and geochronological evidence. Gondwana Res. 25:797-819.

Mao, Q. G.; Xiao, W. J.; Han, C. M.; Fang, T. H.; Sun, M.; and Yuan, C. 2010. The study of Early-Paleozoic peraluminous granite $(\mathrm{SP})$ and its tectonic significance in the Xingxingxia suture zone, eastern Tianshan Mountains, Xinjiang, northwest China. Sci. Geol. Sin. 45:4156.

McDonough, W. F.; and Sun, S. S. 1995. The composition of the Earth. Chem. Geol. 120:223-253.

McLennan, S. M. 1989. Rare earth elements in sedimentary rocks; influence of provenance and sedimentary processes. Rev. Mineral. Geochem. 21:169-200.

McLennan, S. M.; Hemming, S.; McDaniel, D. K.; and Hanson, G. N. 1993. Geochemical approaches to sedimentation, provenance, and tectonics. In Johnsson, M. J., and Basu, A., eds. Processes controlling the com- 
position of clastic sediments. Geol. Soc. Am. Spec. Pap. 284:21-40.

McLennan, S. M., and Taylor, S. R. 1980. Th and U in sedimentary rocks: crustal evolution and sedimentary recycling. Nature 285:621-624.

. 1991. Sedimentary rocks and crustal evolution: tectonic setting and secular trends. I. Geol. 99:1-21.

McLennan, S. M.; Taylor, S. R.; McCulloch, M. T.; and Maynard, J. B. 1990. Geochemical and Nd-Sr isotopic composition of deep-sea turbidites: crustal evolution and plate tectonic associations. Geochim. Cosmochim. Acta 54:2015-2050.

Nance, W. B., and Taylor, S. R. 1976. Rare earth element patterns and crustal evolution-I. Australian post-Archean sedimentary rocks. Geochim. Cosmochim. Acta 40:1539-1551.

Nesbitt, H. W., and Markovics, G. 1997. Weathering of granodioritic crust, long-term storage of elements in weathering profiles, and petrogenesis of siliciclastic sediments. Geochim. Cosmochim. Acta 61:1653-1670.

Nesbitt, H. W., and Young, G. M. 1982. Early Proterozoic climates and plate motions inferred from major element chemistry of lutites. Nature 299:715717.

- 1984. Prediction of some weathering trends of plutonic and volcanic rocks based on thermodynamic and kinetic considerations. Geochim. Cosmochim. Acta 48:1523-1534.

1989. Formation and diagenesis of weathering profiles. I. Geol. 97:129-147.

Pettijohn, F.; Potter, P.; and Siever, R. 1972. Sand and sandstone. New York, Springer.

Qi, L.; Hu, J.; and Gregoire, D. C. 2000. Determination of trace elements in granites by inductively coupled plasma mass spectrometry. Talanta 51:507-513.

Roser, B. P., and Korsch, R. J. 1986. Determination of tectonic setting of sandstone-mudstone suites using content and ratio. I. Geol. 94:635-650.

1988. Provenance signatures of sandstonemudstone suites determined using discriminant function analysis of major-element data. Chem. Geol. 67: 119-139.

Rudnick, R. L., and Gao, S. 2003. Composition of the continental crust. In Rudnick, R. L., ed. The crust. Vol. 3 of Holland, H. H., and Turekian, K. K., eds. Treatise on geochemistry. Oxford, Elsevier-Pergamon, p. 1-64.

Shao, L.; Stattegger, K.; and Garbe-Schoenberg, C. D. 2001. Sandstone petrology and geochemistry of the Turpan basin (NW China): implications for the tectonic evolution of a continental basin. I. Sediment. Res. 71:37-49.

Shi, Y. R.; Jian, P.; Kroner, A.; Jahn, B. M.; Liu, D. Y.; Zhang, W.; and Ma, H. D. 2014. Zircon ages and Hf isotopic compositions of plutonic rocks from the Central Tianshan (Xinjiang, northwest China) and their significance for early to mid-Palaeozoic crustal evolution. Int. Geol. Rev. 56:1413-1434.
Shu, L. S.; Wang, B.; Zhu, W. B.; Guo, Z. J.; Charvet, J.; and Zhang, Y. 2011. Timing of initiation of extension in the Tianshan, based on structural, geochemical and geochronological analyses of bimodal volcanism and olistostrome in the Bogda Shan (NW China). Int. I. Earth Sci. 100:1647-1663.

Su, B. X.; Qin, K. Z.; Sakyi, P. A.; Malaviarachchi, S. P. K.; Liu, P. P.; Tang, D. M.; Xiao, Q. H.; Sun, H.; Ma, Y. G.; and Mao, Q. 2012. Occurrence of an Alaskan-type complex in the Middle Tianshan Massif, Central Asian Orogenic Belt: inferences from petrological and mineralogical studies. Int. Geol. Rev. 54:249-269.

Taylor, S. R., and McLennan, S. M. 1985. The continental crust: its composition and evolution. Oxford, Blackwell.

van de Kamp, P. C., and Leake, B. E. 1985. Petrography and geochemistry of feldspathic and mafic sediments of the northeastern Pacific margin. Trans. R. Soc. Edinb. Earth Sci. 76:411-449.

Wang, B.; Chen, Y.; Zhan, S.; Shu, L. S.; Faure, M.; Cluzel, D.; Charvet, J.; and Laurent-Charvet, S. 2007. Primary Carboniferous and Permian paleomagnetic results from the Yili Block (NW China) and their implications on the geodynamic evolution of Chinese Tianshan Belt. Earth Planet. Sci. Lett. 263:288-308.

Wang, B.; Cluzel, D.; Jahn, B. M.; Shu, L. S.; Chen, Y.; Zhai, Y. Z.; Branquet, Y.; Barbanson, L.; and Sizaret, S. 2014. Late Paleozoic pre- and syn-kinematic plutons of the Kangguer-Huangshan shear zone: inference on the tectonic evolution of the eastern Chinese North Tianshan. Am. I. Sci. 314:43-79.

Wang, B.; Shu, L. S.; Faure, M.; Jahn, B. M.; Cluzel, D.; Charvet, J.; Chung, S. L.; and Meffre, S. 2011. Paleozoic tectonics of the southern Chinese Tianshan: insights from structural, chronological and geochemical studies of the Heiyingshan ophiolitic melange (NW China). Tectonophysics 497:85-104.

Winchester, J. A., and Max, M. D. 1989. Tectonic setting discrimination in clastic sequences: an example from the Late Proterozoic Erris Group, NW Ireland. Precambrian Res. 45:191-201.

Windley, B. F.; Allen, M. B.; Zhang, C.; Zhao, Z.-Y.; and Wang, G.-R. 1990. Paleozoic accretion and Cenozoic redeformation of the Chinese Tien Shan Range, Central Asia. Geology 18:128-131.

Wronkiewicz, D. J., and Condie, K. C. 1987. Geochemistry of Archean shales from the Witwatersrand Supergroup, South Africa: source-area weathering and provenance. Geochim. Cosmochim. Acta 51:2401-2416.

Wu, C. Z.; Zhang, Z. Z.; Gu, L. X.; Tang, J. H.; and Lei, R. X. 2010. Sr, Nd and O isotopic characters of quartz syenite in the Weiya magmatic complex from eastern Tianshan in NW China: melting of the thickened juvenile lower crust. Geochem. I. 44:285-298.

Xiao, W. J.; Li, S. Z.; Santosh, M.; and Jahn, B. M. 2012. Orogenic belts in Central Asia: correlations and connections. I. Asian Earth Sci. 49:1-6. 
Xiao, W. J.; Windley, B. F.; Allen, M.; and Han, C. M. 2013. Paleozoic multiple accretionary and collisional tectonics of the Chinese Tianshan orogenic collage. Gondwana Res. 23:1316-1341.

Xiao, W. J.; Windley, B. F.; Sun, S.; Li, J. L.; Huang, B. C.; Han, C. M.; Yuan, C.; Sun, M.; and Chen, H. L. 2015. A tale of amalgamation of three collage systems in the Permian-Middle Triassic in Central Asia: oroclines, sutures and terminal accretion. Annu. Rev. Earth Planet. Sci. 43:477-507.

Xiao, W. J.; Zhang, L. C.; Qin, K. Z.; Sun, S.; and Li, J. L. 2004. Paleozoic accretionary and collisional tectonics of the Eastern Tianshan (China): implications for the continental growth of Central Asia. Am. I. Sci. 304: 370-395.

Xu, X. Y.; Xia, L. Q.; Ma, Z. P.; Wang, Y. B.; Xia, Z. C.; Li, X. M.; and Wang, L. S. 2006. SHRIMP zircon U-Pb geochronology of the plagiogranites from Bayringou ophiolite in North Tianshan Mountains and the petrogenesis of the ophiolite. Acta Petrol. Sin. 22:83-94 (in Chinese with English abstract).

Yuan, C.; Sun, M.; Wilde, S.; Xiao, W. J.; Xu, Y. G.; Long, X. P.; and Zhao, G. C. 2010. Post-collisional plutons in the Balikun area, East Chinese Tianshan: evolving magmatism in response to extension and slab break-off. Lithos 119:269-288.

Zhang, X. R.; Zhao, G. C.; Eizenhöfer, P. R.; Sun, M.; Han, Y. G.; Hou, W. Z.; Liu, D. X.; Wang, B.; Liu, Q.; and $\mathrm{Xu}, \mathrm{B} .2015 a$. Latest Carboniferous closure of the Junggar Ocean constrained by geochemical and zircon U-Pb-Hf isotopic data of granitic gneisses from the Central Tianshan block, NW China. Lithos 238:26-36. 2015b. Paleozoic magmatism and metamorphism in the Central Tianshan block revealed by $\mathrm{U}-\mathrm{Pb}$ and Lu-Hf isotope studies of detrital zircons from the South Tianshan belt, NW China. Lithos 233: 193-208.

2016a. Late Ordovician adakitic rocks in the Central Tianshan block, NW China: partial melting of lower continental arc crust during back-arc basin opening. Geol. Soc. Am. Bull. 128:1367-1382.

Zhang, X. R.; Zhao, G. C.; Eizenhöfer, P. R.; Sun, M.; Han, Y. G.; Hou, W. Z.; Liu, D. X.; et al. 2016b. Tectonic transition from Late Carboniferous subduction to Early Permian post-collisional extension in the Eastern Tianshan, NW China: insights from geochronology and geochemistry of mafic-intermediate intrusions. Lithos 256257:269-281.

Zhang, X. R.; Zhao, G. C.; Sun, M.; Eizenhöfer, P. R.; Han, Y. G.; Hou, W. Z.; Liu, D. X.; Wang, B.; Liu, Q.; and Xu, B. 2016c. Tectonic evolution from subduction to arccontinent collision of the Junggar ocean: constraints from $\mathrm{U}-\mathrm{Pb}$ dating and $\mathrm{Hf}$ isotopes of detrital zircons from the North Tianshan belt, NW China. Geol. Soc. Am. Bull. 128:644-660.

Zhang, Y. Y.; Yuan, C.; Long, X. P.; Sun, M.; Huang, Z. Y.; Du, L.; and Wang, X. Y. 2017. Carboniferous bimodal volcanic rocks in the Eastern Tianshan, NW China: evidence for arc rifting. Gondwana Res. 43:92106.

Zhang, Z.Z.; Gu, L. X.; Wu, C. Z.; Li, W. Q.; Xi, A. H.; and Shuo, W. 2005. Zircon SHRIMP dating for the Weiya pluton, Eastern Tianshan: its geological implications. Acta Geol. Sin. 179:481-490. 